\title{
Invited review: A systematic review of the effects of early separation on dairy cow and calf health
}

\author{
Annabelle Beaver, ${ }^{1}$ Rebecca K. Meagher, ${ }^{2}$ Marina A. G. von Keyserlingk, ${ }^{1}$ and Daniel M. Weary ${ }^{1 *}$ \\ ${ }_{1}^{1}$ Animal Welfare Program, Faculty of Land and Food Systems, University of British Columbia, 2357 Main Mall, Vancouver, BC, V6T 1 Z4 Canada \\ ${ }^{2}$ School of Agriculture, Policy and Development, University of Reading, Whiteknights, PO Box 217, Reading, Berkshire, RG6 6AH, \\ United Kingdom
}

\section{ABSTRACT}

Concern from the public is growing regarding early cow-calf separation, yet proponents of this practice maintain that artificial rearing is critical for cow and calf health. Early separation is assumed to reduce the risk of transfer of pathogens from dam to neonatal calf, but a wide range of health benefits associated with extended cow-calf contact has also been documented. The aim of this systematic review was to report and synthesize conclusions from the literature on dairy cow and calf health in conventional rearing versus cow-calf contact systems. Peer-reviewed, published manuscripts, written in English, directly comparing dairy cow or calf health in artificial versus suckling systems, were eligible for inclusion. We conducted 7 targeted searches using Web of Science to identify key literature on important health conditions. The resulting manuscripts underwent a 4-step appraisal process, and further manuscripts were sourced from reference lists. This process resulted in a final sample of 70 articles that addressed cow and calf health. Sufficient literature was available to assess mastitis in cows, and scours, cryptosporidiosis, Johne's disease, pneumonia, immunity, and mortality in calves. The results for cryptosporidiosis, pneumonia, immunity, and mortality were mixed, with some differences between studies likely attributable to flawed comparisons between cohorts. Overall, the articles addressing calf scours and mastitis pointed to beneficial or no effects of suckling. The studies addressing Johne's disease did not find cow-calf contact to be a significant risk factor. In conclusion, the scientific peer-reviewed literature on cow and calf health provides no consistent evidence in support of early separation.

Key words: weaning, nursing, cow-calf rearing, udder health, maternal contact

Received August 26, 2018.

Accepted November 6, 2018

*Corresponding author: dan.weary@ubc.ca

\section{INTRODUCTION}

On many commercial dairy farms, it is routine practice to separate the calf from the dam within $24 \mathrm{~h}$ of calving (de Passillé et al., 2008; Stěhulová et al., 2008). Proponents of early separation consider it economically beneficial (due to an increase in saleable milk) and ethically preferable (as it is thought to preclude formation of a maternal bond that becomes progressively more difficult to break; Flower and Weary, 2003).

One oft-cited rationale for immediate cow-calf separation is the health benefit ostensibly afforded by artificial calf rearing. For example, Faubert and Litvinsky (2000) claim that this practice reduces the risk of Cryptosporidium parvum infections. Muskens et al. (2003) make a similar claim for Johne's disease, and Daugschies and Najdrowski (2005) for eimeriosis. However, such literature does not always cite evidence to corroborate these assertions. The concern over disease transmission stems from the agammaglobulinemic state of the neonatal calf and its heightened susceptibility to disease during this time. Artificial feeding of calves is thought to allow better control of colostral quality and quantity and thus improve transfer of maternal immunoglobulins to the calf. Moreover, the dam's fecal coliform count increases by up to $10^{7} \mathrm{cfu}$ during the periparturient period (Pelan-Mattocks et al., 2000), leading to a concern that calves permitted to remain in the calving area are at an increased risk of exposure to pathogens (McGuirk, 2008).

Despite these concerns, health benefits of prolonged contact have been documented for calves and cows, ranging from increased immunoglobulin absorption from colostrum (Stott et al., 1979), to decreased mortality rates for calves (Alvarez et al., 1980), to reduced risk of mastitis for cows (Walsh, 1974). Thus, allowing the cow and calf to remain in contact presents a mosaic of purported health benefits and risks, for which there is a lack of consensus. The aim of the present review is to provide a critical and systematic evaluation of the scientific literature on the health implications of cow-calf contact versus artificial rearing; our compan- 
ion paper (Meagher et al., 2019) presents the results of a parallel review on the effects of cow-calf contact on measures of behavior, welfare, and productivity. A synthesis of conclusions from the literature is required to offer a measure of resolution to this debate.

\section{MATERIALS AND METHODS}

\section{Inclusion and Exclusion Criteria}

Articles were eligible for inclusion if they were peerreviewed, written in English, complete (e.g., conference abstracts were excluded), available in full-text form, and contained a direct investigation of the effects of cow-calf contact or suckling on dairy cow or calf health. Articles were removed if not based upon original data (e.g., review articles or literature-based mathematical models). Any manuscript published after the completion of the literature search (May 18, 2018) was not included. Exclusion and inclusion criteria for the systematic review were developed a priori and agreed upon by all co-authors.

\section{Search Strategy}

Systematic searches were conducted using the Web of Science (WoS) database, which allows for integration of Boolean operators (i.e., AND, OR, NOT) to string together words or phrases, as well as wildcard truncations (denoted as ${ }^{*}$ ) to designate a range of possible word forms. The $\$$ symbol was employed to account for alternate spellings (e.g., American versus British English). All searches contained the following fixed set: ("cow-calf" OR "cow/calf" OR "dam-calf" OR "dam/ calf" OR "dam rearing" OR "reared by the dam" OR "reared by cows "OR "suckling system*" OR "mother rearing" OR "reared by the mother" OR "contact of calves with adult*" OR "leav* calves with dam*" OR "stay* with the dam" OR "remain* with the dam" OR "kept with the dam") AND (nurs* OR suckl* OR separation OR contact OR "risk factor*") AND (calf OR calves).

Seven specific searches were conducted, each containing targeted terms addressing the most relevant calf and cow health conditions: scours (scour* OR diarr*), Cryptosporidiosis (cryptosporidi*), Johne's disease (Johne's OR paratuberculosis), pneumonia (pneumonia OR respiratory), immunity (immunity OR "passive transfer"), health and mortality (disease* OR infection* OR health OR morbidity OR mortality), and mastitis (mastitis OR "intramammary infection*" OR "udder health"). Several additional search terms were tested but yielded no results meeting the predefined exclusion criteria; these terms included "E. coli," Escherichia,
Salmonella, Heidelberg, Clostridium, Campylobacter, "enteric bacteria," coccidi*, BVD, "bovine viral diarr*," rotavirus, coronavirus, neospor*, bluetongue, diphtheria, "Mycoplasma bovis," "Mycobacterium bovis," Schmallenberg, sarcocystis, anaplasm*, cowdria, BLV, "bovine leukemia virus," BIV, "bovine immunodeficiency virus," BoHV-1, BHV-1, "bovine herpes virus," PIV-3, PIV3, "parainfluenza virus," "Mannheimia haemolytica," "Pasteurella multocida," "Histophilus somni," "Arcanobacterium pyogenes," "retained placenta," "placental retention," "\$\$etal membrane," metritis, "uterine health," "uterine disease," "milk fever," hypocalc\$emia, DD, "digital dermatitis," mange, and mites. The selection of these search terms was based upon expert opinion, in addition to several review articles on pathogenesis and health conditions in dairy cows and calves: Mulligan et al., 2006; Muktar et al., 2015; and Francoz et al., 2015.

\section{Selection Process}

Results from the 7 unique searches were pooled, and duplicate results were excluded. Articles were then selected based upon a 4-step screening and appraisal process:

Phase 1. Conference proceedings and articles written in a language other than English were removed. The titles of the remaining articles were scanned to filter out irrelevant results (e.g., literature clearly pertaining to animals other than the dairy cow and calf).

Phase 2. Abstracts were evaluated to identify and remove additional articles not relevant to the topic of dairy cow or calf health, disease, infection, or mortality (e.g., articles addressing dairy-herd economics).

Phase 3. Reference lists were mined for additional relevant manuscripts. If full texts were not available online or in the University of British Columbia's library system, they were requested via interlibrary loan, ResearchGate, or personal contacts. The reference lists of papers added at this stage were also considered as a source for further manuscripts

Phase 4. Finally, review articles were removed, and full texts of the remaining papers were read in detail. Articles containing experimental research were excluded if the experiment itself did not address the question of cow-calf contact (but rather reviewed literature on the issue as part of a larger discussion). Mathematical models were excluded if parameters relating to cow-calf contact were sourced from other literature, or if insufficient information pertaining to real-world data collection was provided to permit recalculation of model parameters.

The articles remaining at this stage were included in the systematic review, and in multiple sections if they 
described more than one relevant effect. To provide a comprehensive overview of the literature, no additional restrictions were placed upon publication year, study type, sample size, or overall quality; however, a quality assessment of the included manuscripts was conducted and is reported in the Appendix.

\section{Data Extraction}

From each manuscript, where applicable, we have recorded authorship, publication year, country, breed of cattle under study, dam-calf contact type (e.g., restricted suckling or unrestricted contact), contact duration, sample size, the amount and type of milk provided to artificially reared calves, the author's conclusion, and the direction of this conclusion. Inter-observer reliability for data extraction (for all categories except for authorship and publication year) was tested on a random subset of 20 articles, with a result of $100 \%$ agreement.

We also present diagnostic test information, relative risks (RR), odds ratios, hazard ratios, and the associated $95 \%$ confidence intervals (CI), where available. These statistics were provided in many of the articles addressing mastitis, Johne's disease, and calf cryptosporidiosis. In an attempt to achieve consistency, we calculated the RR (or prevalence ratio in the case of cross-sectional studies) and CI for articles in these 3 categories if not reported by the authors. This was only possible when sufficient information was provided to permit calculation. The following formulae were applied:

$$
\mathrm{RR}=[\mathrm{a} /(\mathrm{a}+\mathrm{b})] /[\mathrm{c} /(\mathrm{c}+\mathrm{d})],
$$

where a, b, c, and d correspond to number of controls with the disease, number of disease-free controls, number of experimental animals with the disease, and number of disease-free experimental animals, respectively.

$$
\mathrm{CI}=\mathrm{e}^{\ln (\mathrm{RR}) \pm 1.96\{\mathrm{SE}[\ln (\mathrm{RR})]\}},
$$

where $\operatorname{SE}(\operatorname{lnRR})=\sqrt{\frac{1}{\mathrm{a}}+\frac{1}{\mathrm{c}}-\frac{1}{\mathrm{a}+\mathrm{b}}-\frac{1}{\mathrm{a}+\mathrm{c}}}$.

\section{RESULTS AND DISCUSSION}

Results from the 4-step screening and appraisal process detailed in the Materials and Methods section are shown in Figure 1.

Briefly, WoS returned 125 unique papers pertaining to cow-calf separation and health. The titles of these papers were scanned, and 45 papers were subsequently excluded ( 7 of these were written in another language, and 38 concerned beef cattle or other species). Following an assessment of the abstracts $(\mathrm{n}=80)$, an additional 32 papers were excluded. At this stage, 61 articles were sourced from the reference lists of the remaining papers, and from the reference lists of newly included papers. In the final exclusion stage, a further 39 papers were removed because they were review articles $(\mathrm{n}=12)$, did not directly compare cow or calf health in relation to cow-calf contact $(\mathrm{n}=25)$, or were literature-based mathematical models $(\mathrm{n}=2)$. In total, 70 articles (comprised of 29 single-herd studies and 41 multi-herd studies) were selected for inclusion; 9 of these were included in 2 of the specific sections below, and 4 were included in 3 sections.

The final manuscripts included in this systematic review were authored between 1971 and 2016. The studies originated from 6 continents and 30 countries, most commonly North America $(\mathrm{n}=25$ : United States $=15 ;$ Canada $=5 ;$ Mexico $=5)$ and Europe $(\mathrm{n}=20$ : Central Europe $=5$; Scandinavia $=6$; Western Europe = 8; Southern Europe =1). Additionally, 4 studies originated from South America, 4 from East Africa, 5 from Asia (Middle East $=2$; South East Asia $=3$ ), and 3 from Oceania (Australia $=2$; New Zealand $=1$ ). These statistics include only those studies that specified regional information.

The single-herd studies included between 2 and 7 relevant groups with a total sample size of between 4 and 464 animals. The multi-herd studies included between 3 and 2,915 herds with the total number of animals ranging from 240 to 32,622 .

\section{Calf Health}

Scours and Enteric Pathogens. Of the 70 included articles, 16 (11 single herd and 5 multi-herd studies) addressed dairy-calf scours of unspecified or multiple etiologies. Nine additional articles specifically addressed calf cryptosporidiosis, predominantly infection with C. parvum. One of these studies represented a single-herd evaluation of prevalence, and the other 8 were multi-herd trials (between 11 and 248 herds) that paired questionnaires on management practices with cross-sectional or repeated fecal samples from individual calves. Results for scours are reported in Table 1 and results pertaining to Cryptosporidium are reported in Table 2. Two additional articles addressed other enteric pathogens, namely Campylobacter, giardia, Eimeria, rotavirus, and coronavirus.

As shown in Table 1, several studies demonstrated benefits of cow-calf contact on scours (Carias and Vaccaro, 1984; Nocek et al., 1984; Rajala and Castrén, 1995; Weary and Chua, 2000; Boonbrahm et al., 2004a; 
Wagenaar and Langhout, 2007). Conversely, 2 studies (Svensson et al., 2003; Roth et al., 2009) reported a greater risk of scours in dam-reared animals. Roth et al. (2009) hypothesized that the higher incidence in nurs- ing calves could be explained by the increased quantity of milk consumed by these animals, rather than by infectious causes. Indeed, Wagenaar and Langhout (2007) reported that the type of scouring sometimes observed

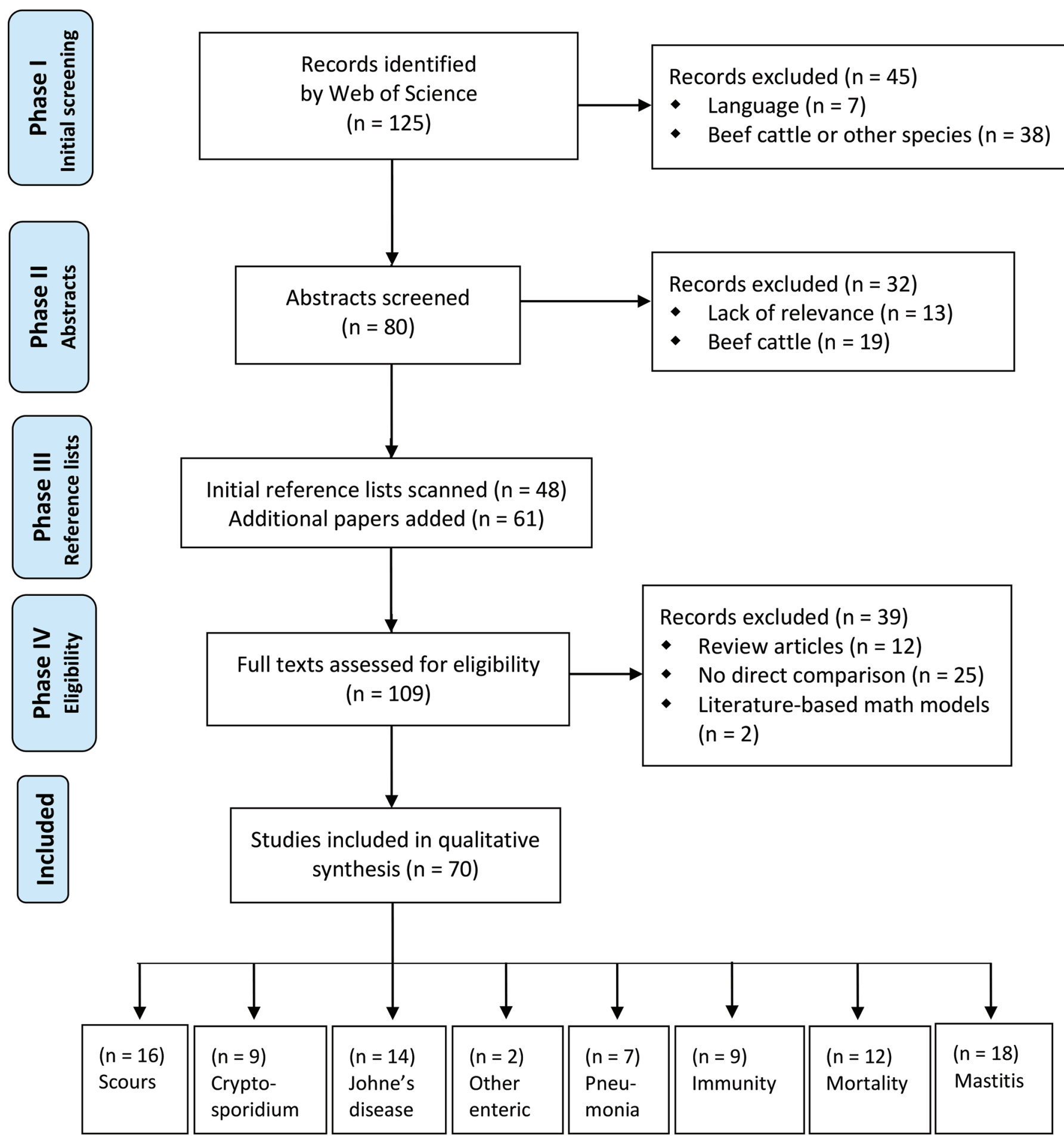

Figure 1. Flowchart depicting the manuscript screening and appraisal process. Note that summing the studies included in the qualitative synthesis in each subsection yields 87 studies, rather than 70 . This discrepancy results from the inclusion of 9 studies in 2 specific sections and 4 studies in 3 specific sections. A deletion of the duplicates results in 70 unique studies. 


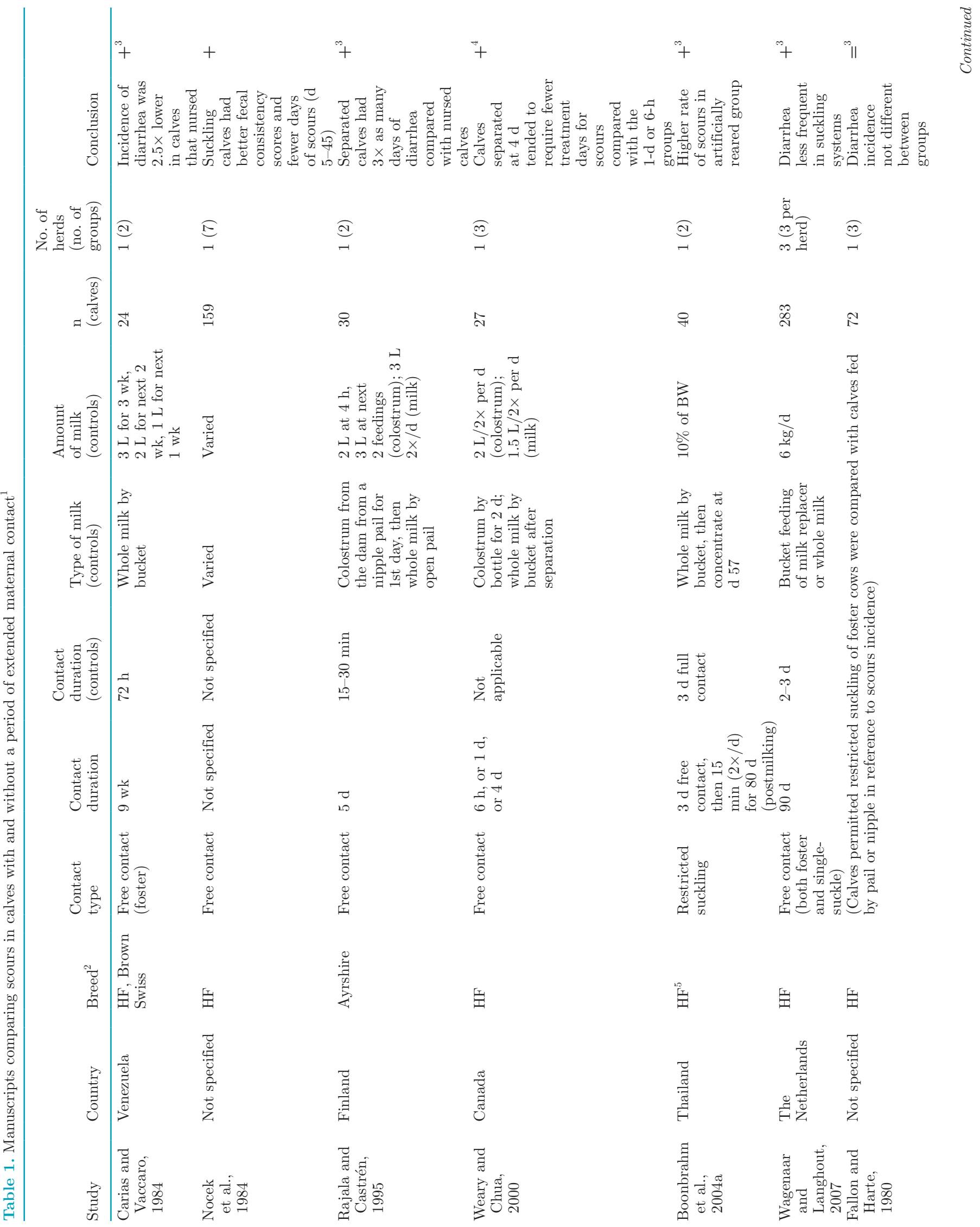


INVITED REVIEW: HEALTH EFFECTS OF EARLY SEPARATION

5789

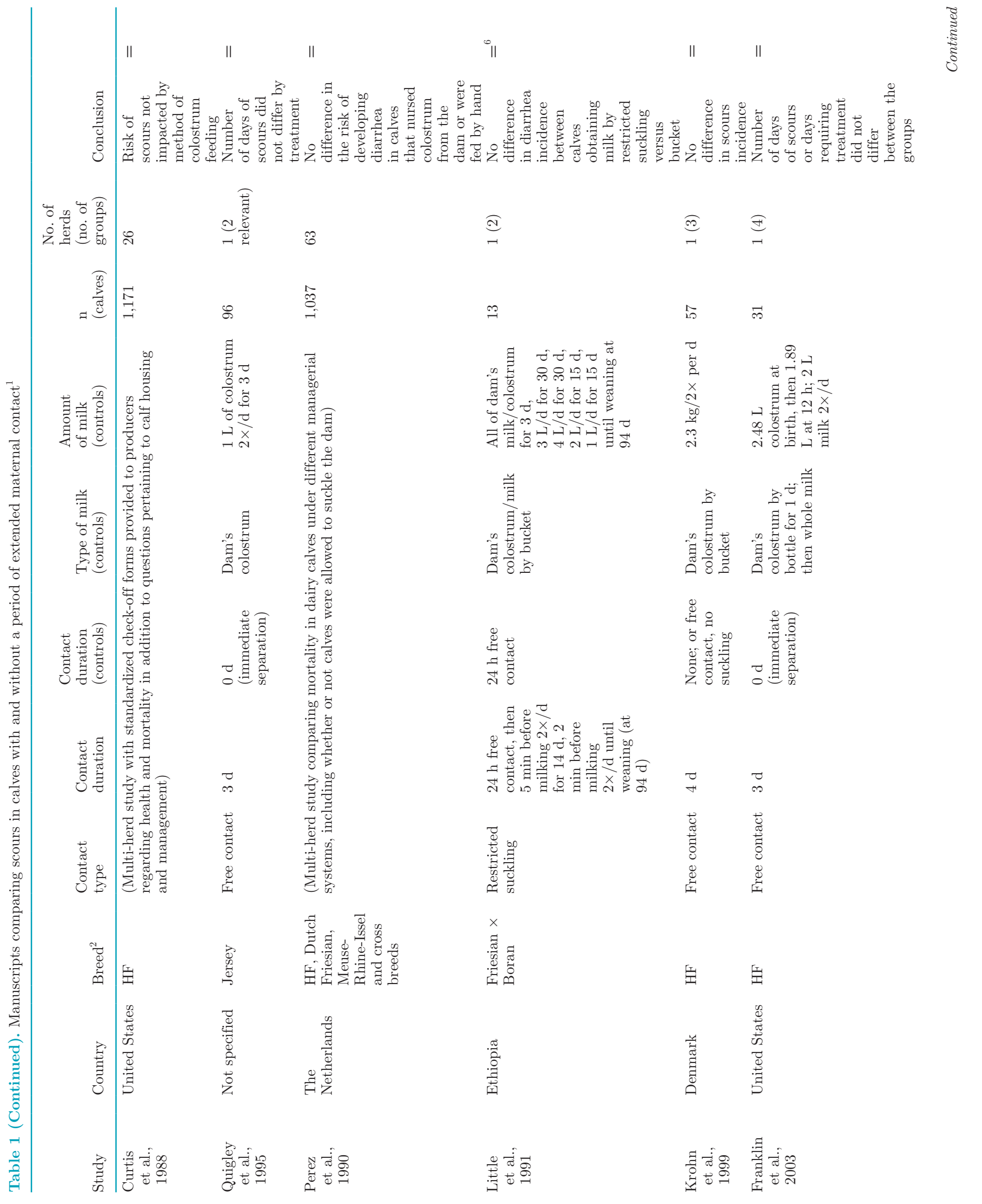


BEAVER ET AL.

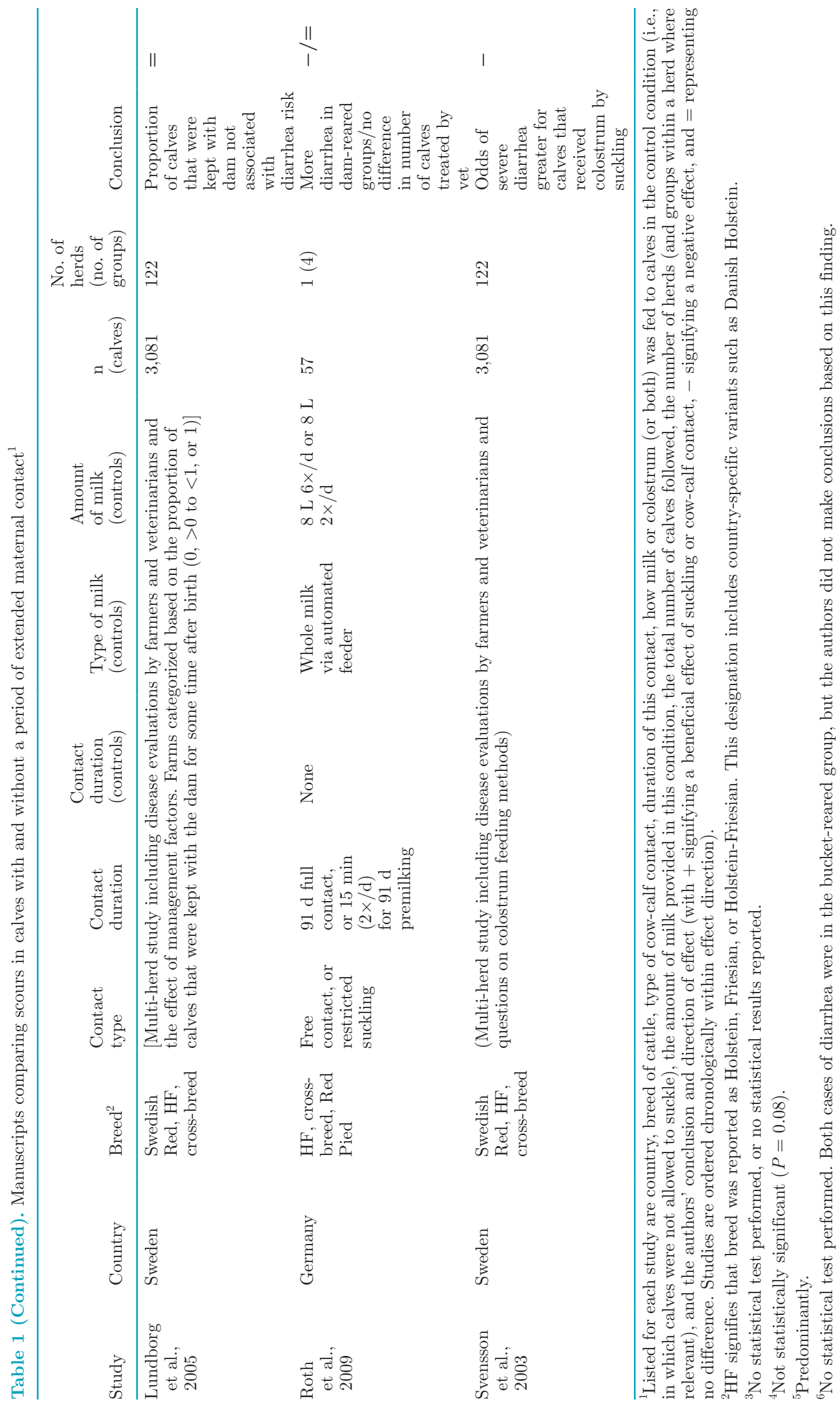


INVITED REVIEW: HEALTH EFFECTS OF EARLY SEPARATION

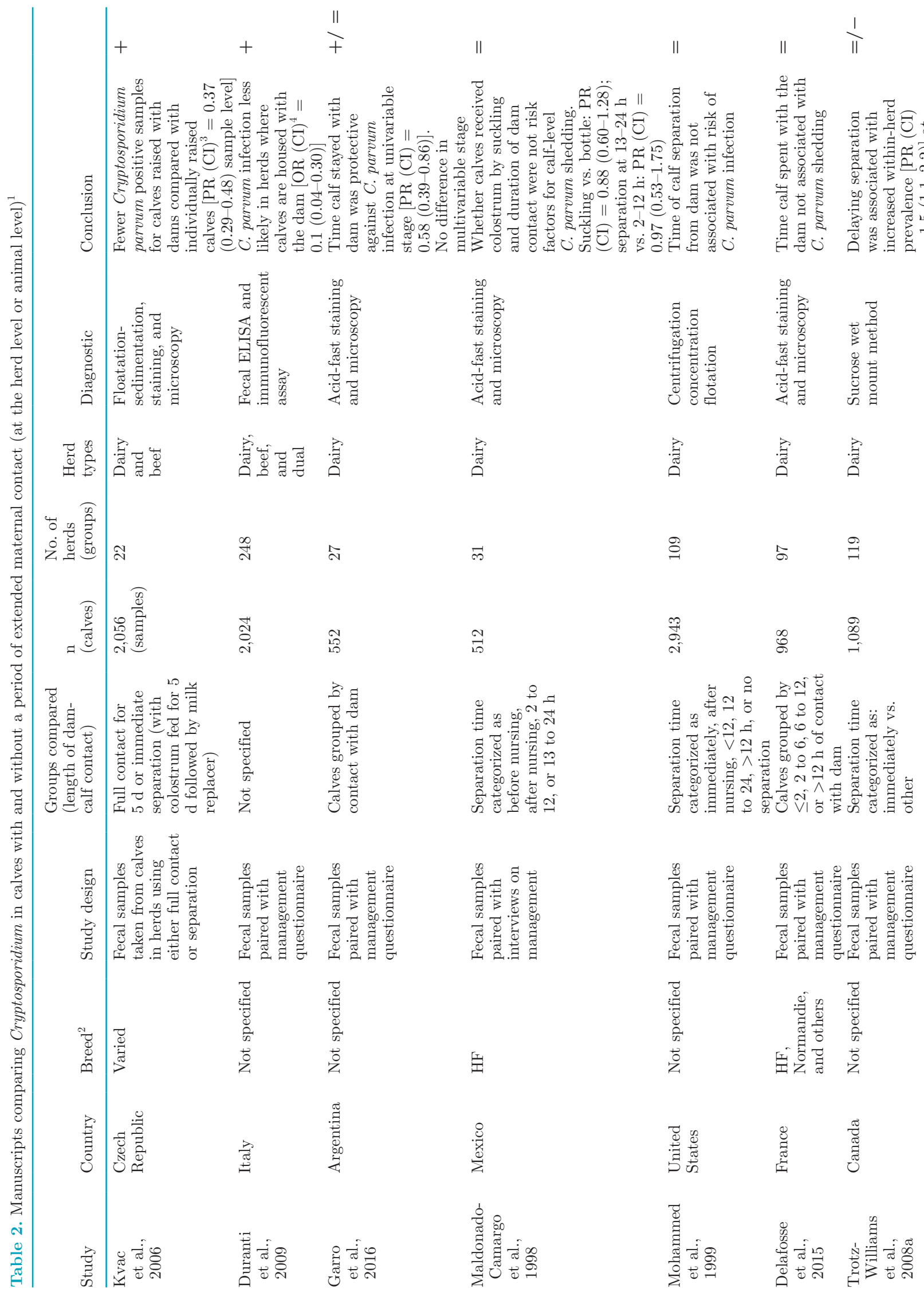




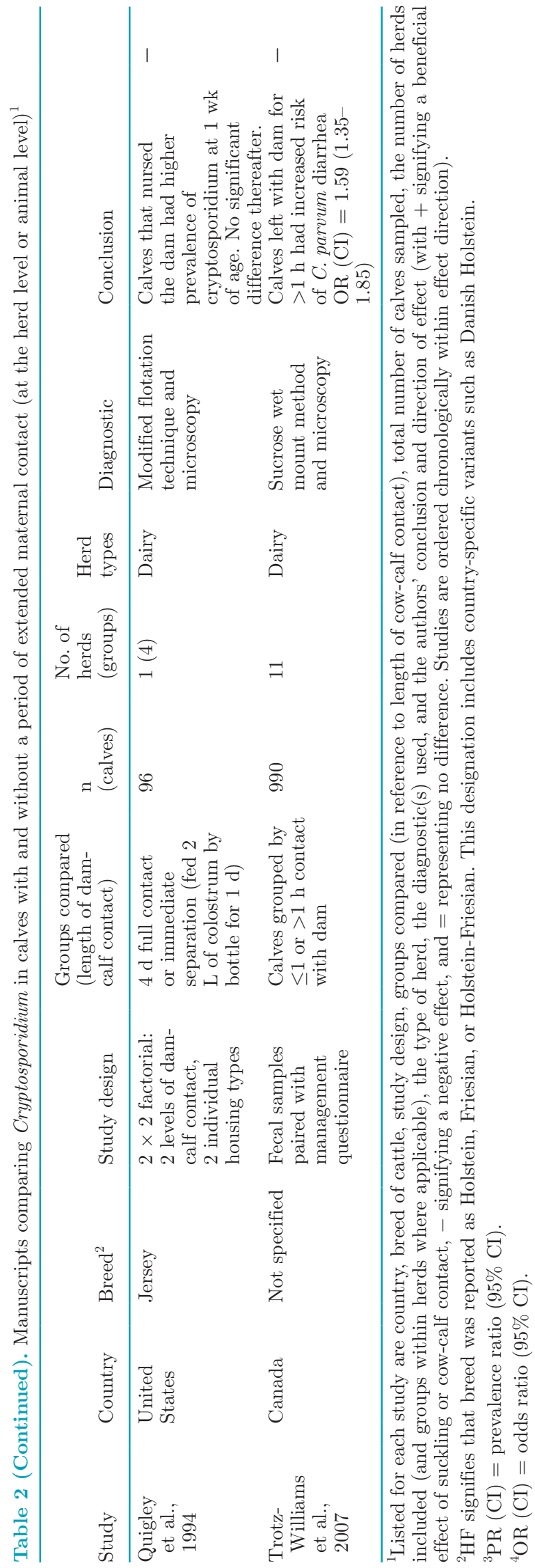

in suckling calves was characteristically distinct from that of bucket-fed counterparts, primarily because it did not lead to the animals dirtying their backsides. Boonbrahm et al. (2004a) found that mortality from scours and other conditions was higher in bucket-fed calves (15\%) compared with dam-reared calves $(0 \%)$, again suggesting a different etiology. It is now well known that high volumes of milk may contribute to looser manure in calves (see Khan et al., 2011), which need not reflect any infection. Methods of evaluating scours in calves should therefore take into account differences in fecal consistency associated with level of milk intake.

Although the balance of the research seems to point to either neutral or positive effects of dam rearing on calf scours, results are mixed with respect to Cryptosporidium (see Table 2). Two of the 9 included studies reported a protective effect of the dam's presence (Kvac et al., 2006; Duranti et al., 2009), 4 reported no difference (Maldonado Camargo et al., 1998; Mohammed et al., 1999; Delafosse et al., 2015; Garro et al., 2016), and the remaining 3 (Quigley et al., 1994; Trotz-Williams et al., 2007, 2008a) indicated that dam-calf contact increases the risk of infection. This lack of consensus may stem from variation in study design and outcome measurements (e.g., herd versus sample-level prevalence), in breed (dairy versus mixed dairy-beef), or in the diagnostic methods chosen. Despite the conflicting results, the collective burden of available odds ratios and risk ratios is skewed toward a protective effect of suckling.

Two papers addressed other specific enteric pathogens in relation to dam-calf contact. Klein et al. (2013) found that herds leaving calves with the dam for $>1$ $\mathrm{h}$ had a 2.6 times greater odds of testing positive for Campylobacter spp., and Quigley et al. (1994) noted an increased risk of Giardia in suckling calves, but no differences were found for Eimeria, rotavirus, or coronavirus; further investigation of these and other pathogens in suckling systems is needed.

Johne's Disease. Of the 70 articles included, 14 directly addressed the relationship between the prevalence of Mycobacterium avium ssp. paratuberculosis (MAP; the causal agent of Johne's disease) and duration of cow-calf contact. All 14 studies consisted of management questionnaires paired with serum $(\mathrm{n}=5)$ or milk $(\mathrm{n}=2)$ ELISA testing, unspecified ELISA testing $(\mathrm{n}=1)$, bulk-milk PCR $(\mathrm{n}=1)$, fecal culture $(\mathrm{n}=$ 1), a combination of fecal culture and serum ELISA ( $\mathrm{n}$ $=1)$, or clinical case reports $(\mathrm{n}=3)$. Results are shown in Table 3.

A limiting factor in many of the cross-sectional studies presented in this review is the absence of a temporal relationship between Johne's diagnosis and the imple- 
mentation of management practices. However, none of the included articles were able to identify increased MAP prevalence among herds permitting cow-calf contact, even in preliminary univariable analyses (with the exception of Pillars et al., 2011). Official Johne's disease control programs frequently describe the risks associated with allowing the calf to suckle and remain within the maternity area, or directly recommend immediate separation of cow and calf following parturition; such programs include the Three Step Calf Rearing Plan of Australia (Animal Health Australia, 2016), the Voluntary Bovine Johne's Disease Control Program of the United States (USDA, 2010), and several regionspecific Canadian programs [such as the Atlantic Veterinary College (2015) Johne's Disease Initiative, which deems calf nursing to be a risky practice, even within test-negative herds]. Given the lack of quantitative evidence on the value of immediate cow-calf separation, the persistence and regularity of this recommendation is surprising.

A common theme that emerged in our systematic search of this topic was the presence of unsubstantiated claims regarding MAP prevalence and cow-calf separation. An example of the dissemination of such claims within the literature is shown in Figure 2.

The type of citation scheme demonstrates how a largely unsubstantiated claim (in this case, that calves should be immediately separated from the dam to prevent Johne's disease) can achieve the status of "common knowledge" in the literature. The perpetuation of these assertions may lead to decisions such as that of Norton et al. (2009) to include "duration of dam-calf contact" in multivariable risk assessment modeling due to "biological importance," despite the variable's lack of significance at the univariable screening stage.

The hypothesis regarding biological relevance is not unfounded because calves under 6 mo of age are most susceptible to MAP infection. Mycobacterium avium ssp. paratuberculosis may be transmitted from an infected dam to calf in utero or through direct bacterial shedding into colostrum or milk; however, MAP infection occurs predominantly by means of a contaminated environment, via the fecal-oral route (Lombard, 2011). We may thus imagine that prompt calf removal could mitigate transmission. Several mathematical models (e.g., Collins and Morgan, 1991; Marcé et al., 2011) have demonstrated that removing the calf from the calving area, or minimizing the effective number of cow-calf contacts, reduces MAP prevalence, but such models are often parameterized based upon an assumption that transmission increases for calves contacting adult animals. Yet, in some herds, cow-calf separation has supplanted control strategies for which concrete evidence exists to tie the respec- tive strategy to a reduction in MAP prevalence. For example, Wells and Wagner (2000) noted that herds in which cows and calves were separated at $1 \mathrm{~h}$ (compared with $>24 \mathrm{~h}$ ) were more than 3 times as likely to have had a previous Johne's disease diagnosis. The authors posit that herd managers altered their management practices following the positive herd status report. In contrast, the practice of sourcing $>25 \%$ of animals from outside dairies was associated with a current Johne's disease diagnosis in the herd, yet no evidence was provided to suggest that this practice underwent a similar modification (Wells and Wagner, 2000). Johnson-Ifearulundu and Kaneene (1998) reported that the process of cleaning maternity pens was linked to a 3 -fold reduction in the odds of a positive herd-level MAP status. However, many commercial herds allow multiple animals in the calving area (e.g., $59 \%$ in the United States; USDA, 2016) or permit sick cows to be housed in these areas (25\%). Of those herds that did use dedicated individual maternity pens, only 20 to $34 \%$ (depending on herd size) cleaned the area after each calving (USDA, 2016). There is evidence for a synergism of infection risk in the calving area, based upon the level of environmental cleanliness, udder hygiene, and presence of other lactating animals (Beaver et al., 2016). The evidence we have reviewed indicates that prompt calf removal should not be viewed as a substitute for proper hygiene and management in the maternity area.

Respiratory Health. Of the 70 included articles, 7 (3 single-herd and 4 multi-herd studies) addressed respiratory health in dairy calves. The results of these studies are shown in Table 4.

The majority of these papers did not investigate pneumonia as a primary outcome measure; all but one study (Gulliksen et al., 2009a) was included in other subsections of this review. Five studies failed to find any association between respiratory risk and dam-calf contact or nursing (although 2 of these studies were conducted using the same group of calves: Lundborg et al., 2005, and Svensson et al., 2003). The remaining 2 studies presented opposing conclusions, with Gulliksen et al. (2009b) reporting a higher risk of pneumonia for calves kept $>24 \mathrm{~h}$ with the dam and Boonbrahm et al. (2004a) noting a lower pneumonia incidence in suckling calves. Further research is clearly required before meaningful conclusions can be reached, including studies for which the investigation of specific respiratory pathogens is a primary objective.

Immunity. Of the 70 included articles, 9 described calf immunity or failure of passive transfer (FPT) in suckling compared with artificial systems. The majority $(\mathrm{n}=6)$ were single-herd trials, and 3 were multi-herd studies (Table 5). 


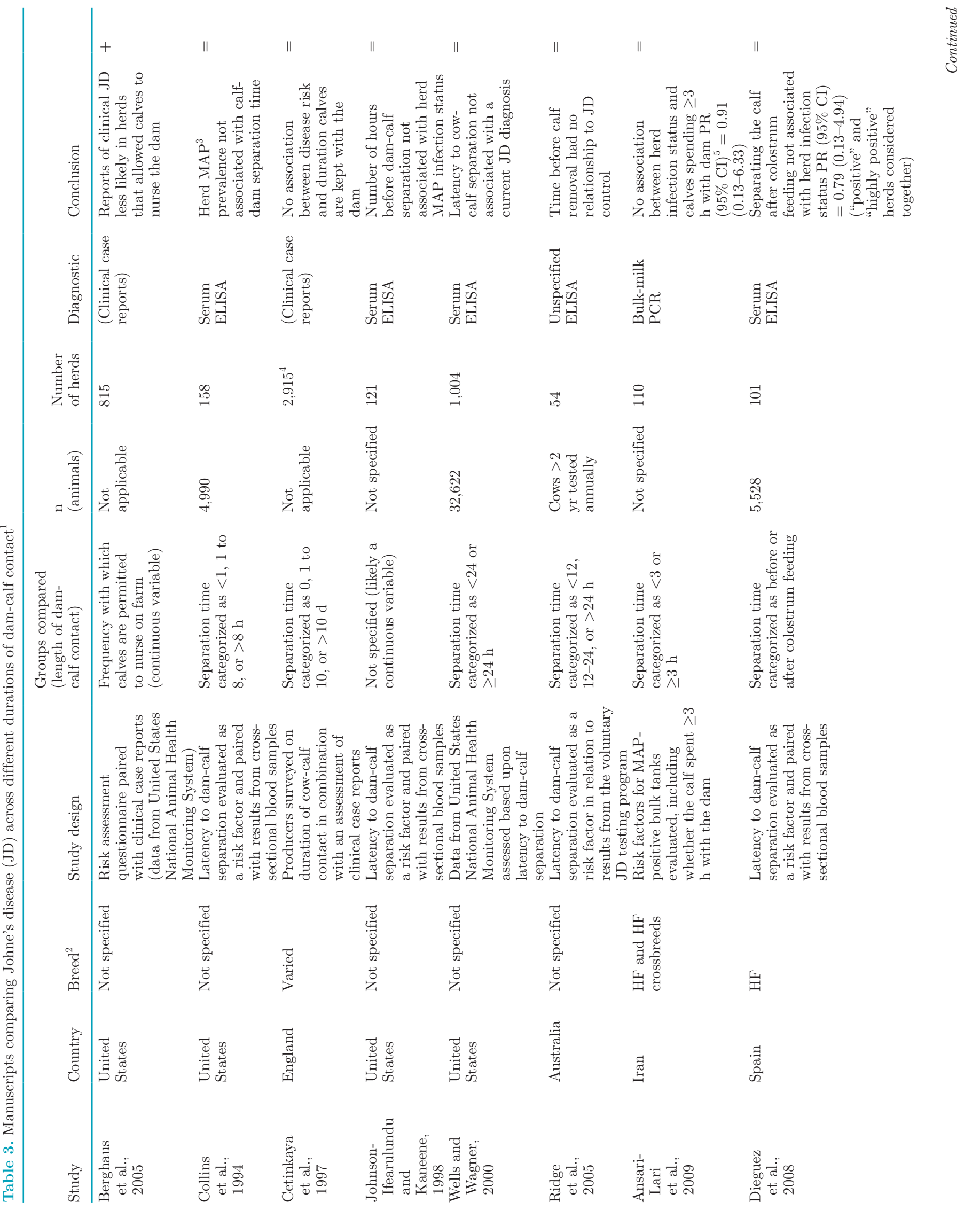


INVITED REVIEW: HEALTH EFFECTS OF EARLY SEPARATION

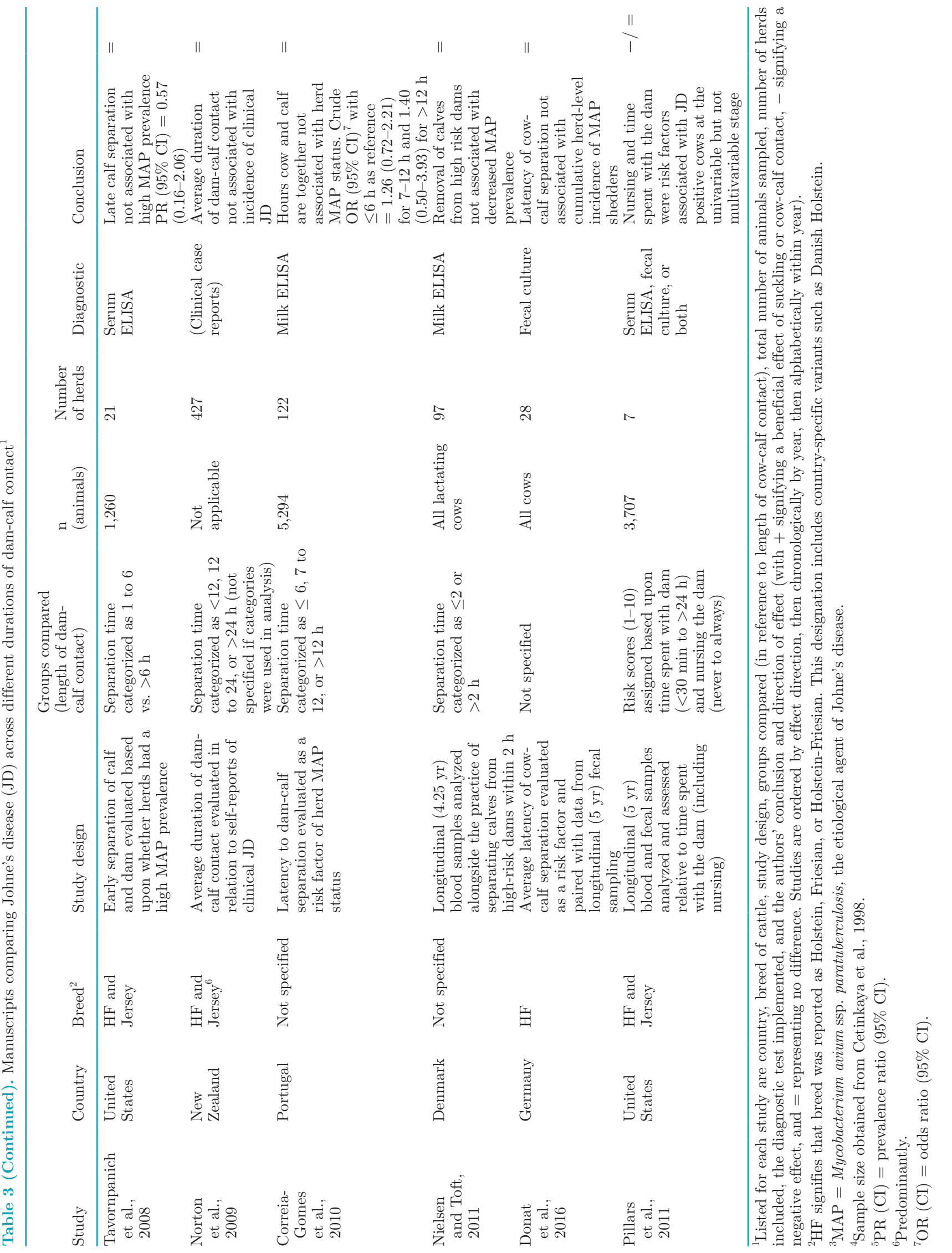


The cited studies present conflicting conclusions. For example, Stott et al. (1979) and Quigley et al. (1995) described a positive association between suckling and immunoglobulin absorption in neonatal calves, and Selman et al. (1971) found that the presence of the dam led to improved passive transfer. In contrast, several articles concluded that suckling results in higher levels of FPT (Nocek et al., 1984; Besser et al., 1991; Trotz-Williams et al., 2008b; Beam et al., 2009). This discrepancy may, in part, be traced back to the source and quantity of colostrum offered to control groups. It is now well established that quantity, quality, and promptness of colostrum administration is pivotal in facilitating immunoglobulin absorption and thus lowering the rate of FPT (see Godden, 2008). The current recommendation stipulates that calves obtain 10 to $12 \%$ of their BW in colostrum at first feeding, and additional benefits have been shown in calves receiving further doses of colostrum at $12 \mathrm{~h}$ postpartum (Godden, 2008). In several of the older studies (Stott et al., 1979; Quigley et al., 1995), the volume of colostrum fed to control groups would be considered insufficient by today's standards, and is likely not comparable to the amount a suckling calf would obtain from the dam. Moreover, in Stott et al. (1979) the colostrum provided to control calves was pooled; pooling has been reported to increase the bacterial burden, leading to inhibition of immunoglobulin absorption (Stewart et al., 2005). Thus, differences in FPT between dam-reared and artificially raised calves may be attributable to colostrum allowance.

Other studies seeking to compare rates of passive transfer between the 2 groups are often encumbered by different limitations. Besser et al. (1991) collected data from 3 separate herds, each with different colostrum management practices (tube feeding, bottle feeding, or suckling). Because these herds likely differed in a variety of other dimensions, and successful immunoglobulin absorption is affected by numerous external factors (Godden, 2008), it is difficult to isolate the effect of suckling. Besser et al. (1991) made some effort to measure colostrum quality in all groups, but large volumes were fed to the control animals, and the authors acknowledge that these would far exceed the expected intake of a suckling calf. In Nocek et al. (1984) and Beam et al. (2009), calves fed high-quality and promptly administered colostrum were compared with an unmonitored suckling group, with unknown colostral quality and latency to feed. Thus, the same concerns regarding insufficient colostrum allowance (Stott et al., 1979; Quigley et al., 1995) are replicated, but in this case, are transferred to the suckling group.

Several other studies have addressed the question cow-calf removal and FPT without drawing a direct comparison between artificial rearing and suckling systems. For example, McAloon et al. (2016) found that increased time spent in the calving pen was associated with diminished immunoglobulin absorption, likely because many calves did not suckle in the first few hours after birth. Arguably, these conclusions are attributable to latency until farmer intervention rather than time spent with the dam, per se. Producers aim to provide prompt administration of high quality colostrum to separated calves and could provide similar interventions for the suckling calf.

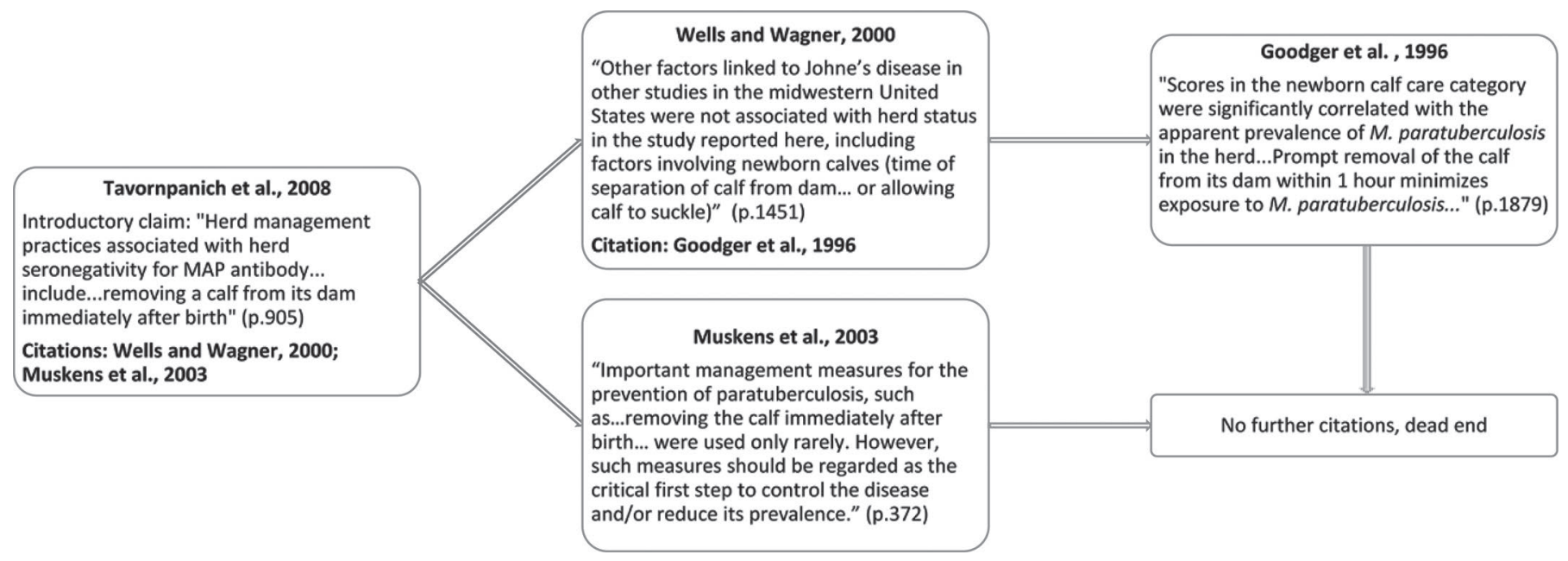

Figure 2. Example of a chain of citations in the Johne's disease literature evaluating the claim that immediate cow-calf separation reduces Johne's disease prevalence. Newborn calf care (Goodger et al., 1996) represents an aggregate of the following management practices: (1) whether colostrum was harvested from a clean udder (free of manure), (2) whether the bottles used to store colostrum were clean, (3) whether colostrum was pooled, and (4) whether calves were permitted extended contact with the dam. MAP $=$ Mycobacterium avium ssp. paratuberculosis. 
INVITED REVIEW: HEALTH EFFECTS OF EARLY SEPARATION

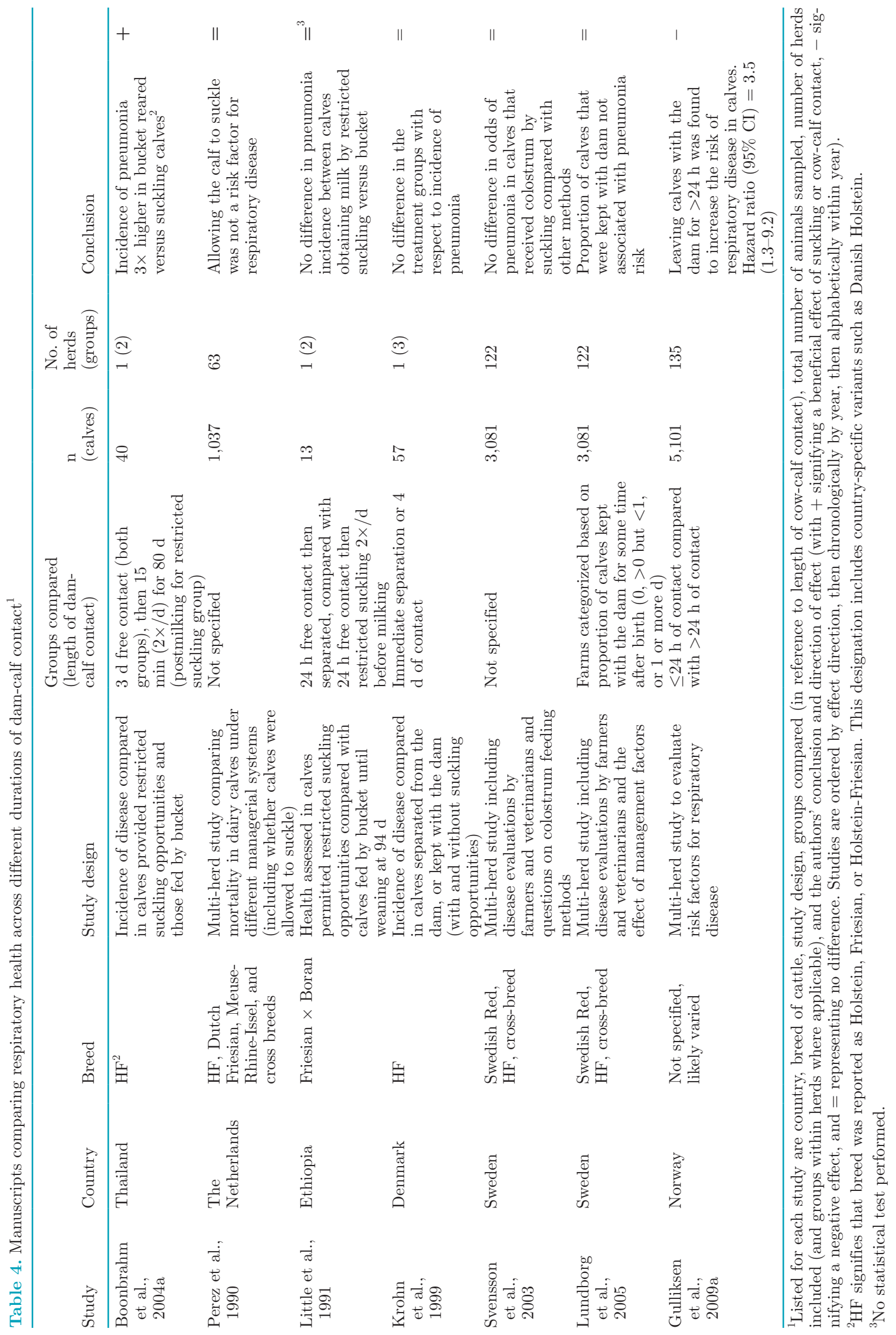




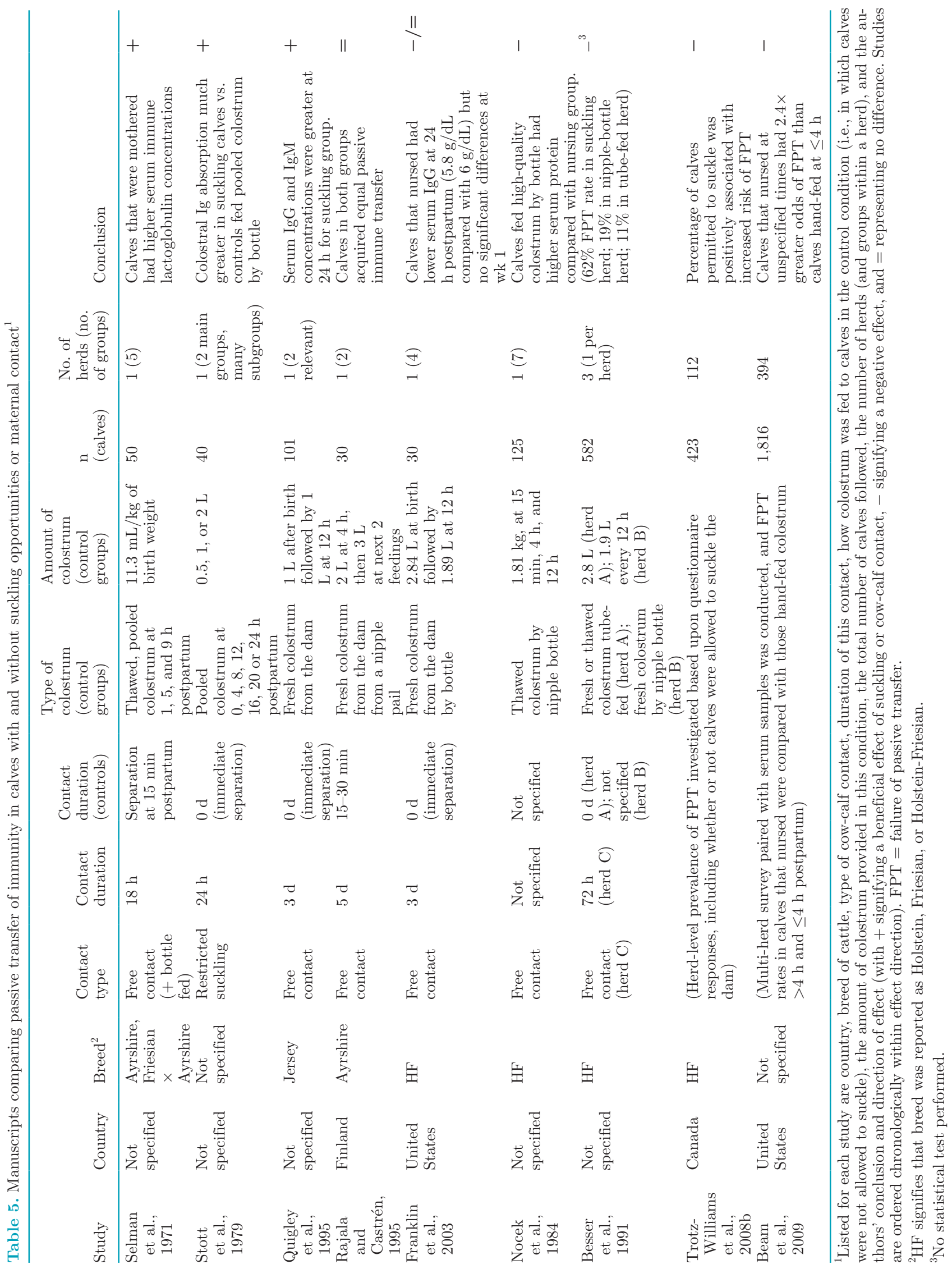


It is important to recognize that a large proportion of dairy calves left with the dam fail to nurse within $6 \mathrm{~h}$ after parturition ( $46 \%$ of calves born to dams of second or higher parity; Edwards and Broom, 1979). Calves may exhibit a higher latency to suckle if they have low vigor or if the dam has experienced a difficult calving (Rajala and Castrén, 1995). Thus, the farmer cannot rely upon nature alone but rather should supervise and intervene if necessary to promote adequate passive immune transfer to the calf. Calves born to dams with low-hanging udders (Ventorp and Michanek, 1992) may also have more difficulty obtaining colostrum by suckling, suggesting that these calves in particular could benefit from active assistance with nursing or administration of colostrum by bottle. Together these observations indicate that various types of farmer intervention, including careful observation and supplementary feeding, may be beneficial regardless of whether the calf is separated from the cow.

Given that bacterial contamination of colostrum can interfere with immunoglobulin absorption (see Godden, 2008), it is useful to compare bacterial counts in directly stripped colostrum (which a suckling calf would be expected to obtain) and corresponding counts in harvested and stored colostrum sources. One study (Stewart et al., 2005) found that the process of harvesting colostrum into a bucket resulted in dramatically higher bacterial counts than in directly stripped colostrum. Additionally, bacteria in colostrum can multiply precipitously when kept at ambient room temperature and may even reach concentrations exceeding 1,000,000 $\mathrm{cfu} / \mathrm{mL}$ after $48 \mathrm{~h}$ of refrigeration (Stewart et al., 2005). Bacterial growth in colostrum may add variation to how calves perform when fed by bucket or teat; artificial colostrum feeding is therefore likely to work best on farms able to mitigate this risk (e.g., through decontamination of storage containers).

Thus there may be challenges and benefits associated with both hand feeding and nursing colostrum from the dam. Given the conflicting evidence presented, and the flawed comparisons between groups, the common recommendation to separate the cow and calf immediately after parturition to ensure successful immune transfer should not be considered to be evidence based. However, leaving the calf unsupervised with the dam cannot serve as a replacement for careful colostrum management.

Mortality. Of the 70 included articles, 2 addressed the subject of general calf health and 10 directly addressed calf mortality. Six were single-herd trials and the remaining 6 incorporated between 26 and 906 herds, with data obtained from questionnaires or surveys on management practices and calf mortality rates (Table $6)$.
There appears to be little consensus regarding mortality in dam-reared versus conventionally raised calves. The reasons for this variation are likely similar to those previously described for the FPT outcomes. That is, conventionally reared calves may be at risk when study methodology results in inadequate colostrum uptake (as in Quigley et al., 1995). Insufficient colostrum quantity has been definitively linked to FPT, which, in turn, has strong associations with mortality (see Godden, 2008). Similarly, dam-reared calves may experience increased mortality rates when colostrum intake is unmonitored, unaided, or not quality-controlled. The confounding of dam rearing with low-input management may account for the conclusions from large-scale, multi-herd studies such as Jenny et al. (1981) and Wells et al. (1996). Indeed, Jenny et al. (1981) stated that farmers leaving calves with the dam may wrongly assume these calves have obtained sufficient colostrum via suckling. In contrast, farmers separating the calf and dam must undertake the "mothering role" themselves and provide individualized attention.

Waltner-Toews et al. (1986) noted an interesting phenomenon in calves provided assistance at suckling. In this study, calves that suckled colostrum naturally were less likely to require treatment for disease than were calves fed colostrum by bucket; however, calves requiring assistance to suckle also had higher odds of being treated for disease compared with calves suckling naturally. These findings could indicate that farmers were more concerned about the assisted suckling group and therefore were more likely to provide treatment, or that these animals were "weak calves to begin with" (p. 154) and thus required more treatment. In any case, these findings do not imply that suckling assistance itself leads to increased disease rates.

\section{Cow Health: Mastitis}

Of the 70 included articles, 18 addressed mastitis in dairy cows. Of these, 16 were conducted using a single herd, wherein 2 to 4 groups were evaluated. The cohorts typically consisted of cow-calf pairs in either full or restricted-suckling systems in addition to variants of artificially reared controls; however, one of these articles (Wagenaar et al., 2011) addressed the future udder health of heifer calves raised under contrasting management conditions. Of the remaining multi-herd studies, one evaluated cohorts across 3 separate herds, and the other employed a questionnaire on management paired with clinical mastitis assessments for 105 herds. The assessments of udder health and mastitis rates were conducted using The California Mastitis Test (6), The Rapid Mastitis Test (1), The Wisconsin Mastitis Test (1), The Whiteside Test (1), SCC or SCS 
(4), electrical conductivity (1), or unspecified methods (4). Table 7 lists the 18 included studies.

Consistent with the findings of Johnsen et al. (2016), the studies reviewed here demonstrate a beneficial effect of suckling systems in reducing the risk of mastitis in dairy cows. In addition to the advantages of suckling to remove residual milk from the udder, reduced mastitis rates in suckled cows could be attributed to lysozymes for bacterial inhibition present in calf saliva (Mdegela et al., 2004). No study in our systematic review demonstrated an increased risk of IMI in suckled cows; however, one study did report higher rates of teat damage (Thomas et al., 1981). This damage was most pronounced in cows suckling 4 calves twice daily for 8 wk compared with machine milking. These authors recommend nursing for shorter durations to prevent the temporary teat damage associated with continuous, long-term suckling. Walsh (1974) found that the greatest benefits in mastitis prevention afforded to nursing cows were in early and mid-lactation. Together, these results suggest that producers interested in reducing the risk of mastitis should consider the use of suckling, particularly in early lactation (see also Kälber and Barth, 2014).

\section{SUMMARY OF KEY FINDINGS AND DIRECTIONS FOR FUTURE RESEARCH}

We systematically reviewed literature on the effect of suckling on calf health, with an emphasis on calf enteric health (including general scours, cryptosporidiosis, and Johne's disease), respiratory health, immune status, and mortality. In sum, the evidence presented in this review does not support the recommendation of immediate separation to promote calf health. Specifically, we found no consistent evidence of increased risk of pneumonia in calves reared with the cow; however, the available literature on this subject was limited and often did not address the subject of respiratory health as a primary research objective. With respect to enteric health, the majority of studies demonstrated that rearing the calf with the dam had no effect on scours, or was associated with a reduced risk. Future research should aim to identify differences in etiology (e.g., infectious versus nutritional causes) between scours in dam-reared compared with artificially reared calves. The leading cause of mortality in dairy calves is diarrhea, for which a wide variety of enteric pathogens are responsible (Cho and Yoon, 2014). With the exception of $C$. parvum (for which the evidence was mixed), common pathogenic causes of scours in the dairy calf have not been evaluated in detail in artificial compared with suckling systems (apart from the work of Klein et al., 2013, and Quigley et al., 1994).
Johne's disease is commonly considered an important risk associated with cow-calf contact, but we could find little evidence that rearing the calf with the dam increases MAP prevalence. Contact with the dam after birth cannot be considered an appropriate surrogate variable for "contact with adult cow manure," unless aspects of cow hygiene, colostrum management, maternity-pen management, and overall cleanliness of the calving area are poorly governed. As several these variables have been strongly associated with MAP transmission risk (e.g., see Ansari-Lari et al., 2009; Tiwari et al., 2009; Donat et al., 2016), initiatives to improve these measures should be prioritized over cowcalf separation. More targeted longitudinal research is required to assess whether immediate cow-calf separation provides any substantive benefit across herds with differing cow-level prevalence.

For measures of calf immunity and mortality, no consistent pattern was observed, with studies split between those showing benefits versus risks associated with suckling. Studies demonstrating benefits associated with suckling typically did not provide sufficient colostrum or milk to the artificially reared calves. Similarly, articles detailing the risks of leaving the calf with the dam did not systematically monitor colostrum intake, quality, and suckling latency. Interestingly, our systematic review uncovered only a single study addressing immunity and one addressing mortality authored within the last decade (Beam et al., 2009, and Gulliksen et al., 2009b, respectively). In Nocek et al. (1984), several experimental groups were completely deprived of colostrum. Given our current knowledge of the importance of colostrum quality, quantity, and timeliness of provision, further studies should assess the feasibility of keeping the calf with the dam and providing supplemental high-quality colostrum as soon as possible after parturition.

The results of our systematic search into the effects of suckling systems on dairy cow health do not indicate any benefit to early separation. All of the studies included in this review demonstrated a reduced risk of mastitis in nursing dairy cattle or reported no difference. Mastitis is one of the most prevalent disorders in dairy systems worldwide, and some evidence suggests that incidence is on the rise in North American herds (see USDA, 2007, versus USDA, 2018). As mastitis is also, arguably, the most economically significant challenge facing dairy producers (see Seegers et al., 2003; Jamali et al., 2018), the favorable conclusions with regard to dam-calf suckling should not be taken lightly. Our conclusions on mastitis are in agreement with other reviews on this topic (e.g., Kamboj and Kumar, 2013; Kälber and Barth, 2014; Johnsen et al., 2016); the consensus among these authors is that some type of 
INVITED REVIEW: HEALTH EFFECTS OF EARLY SEPARATION

5801

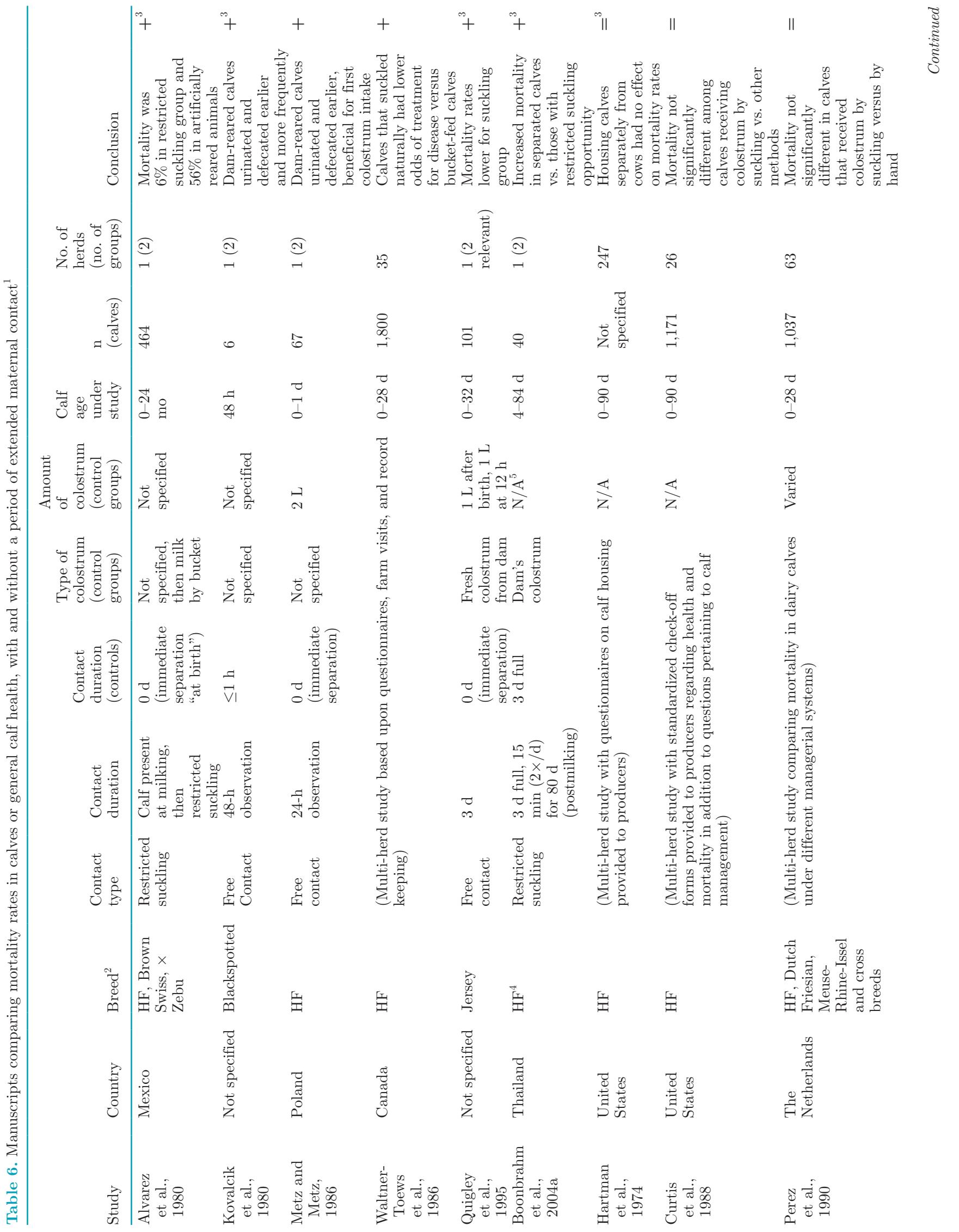


BEAVER ET AL.

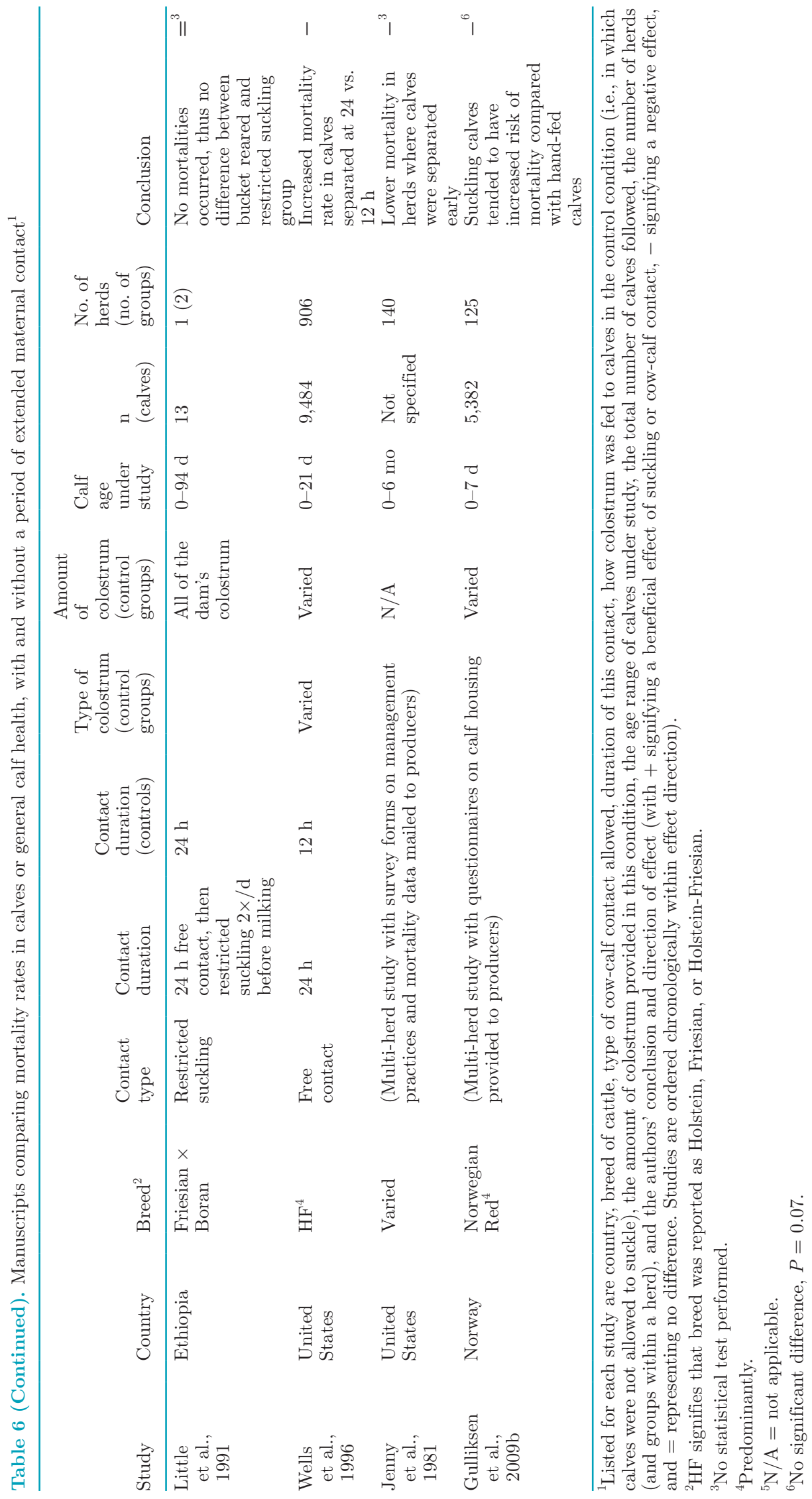


INVITED REVIEW: HEALTH EFFECTS OF EARLY SEPARATION

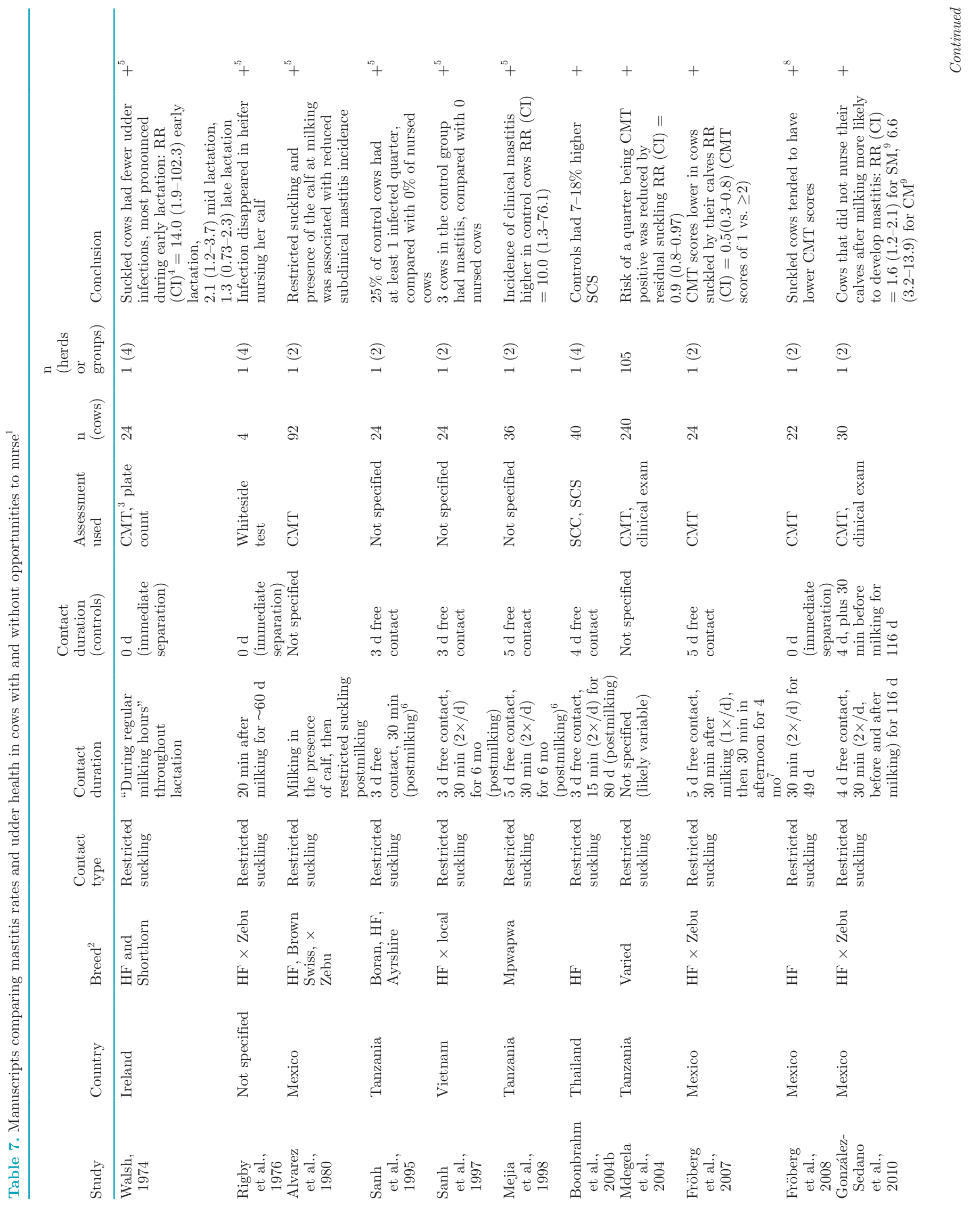


BEAVER ET AL.

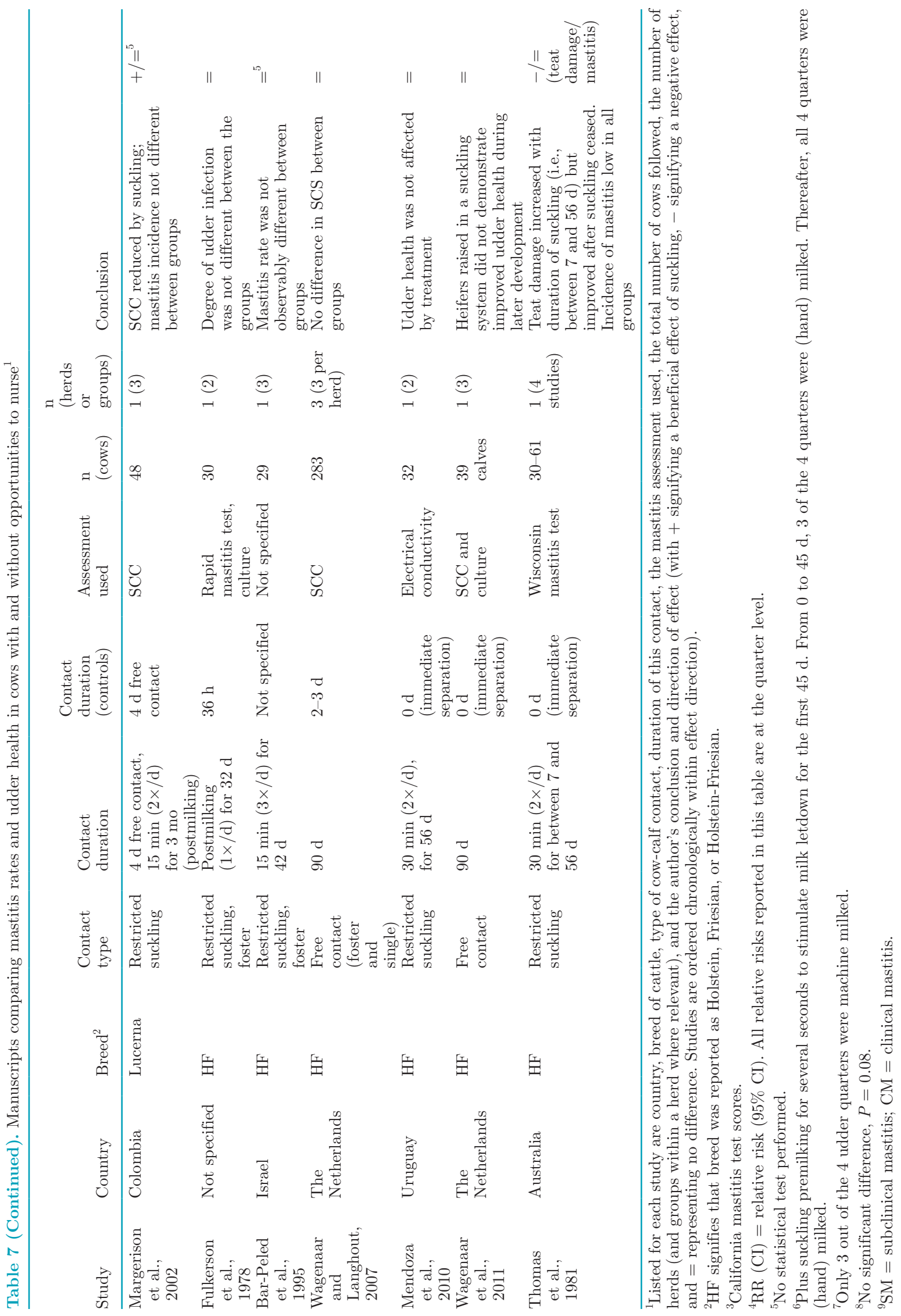


restricted suckling system has the potential to reduce mastitis on dairy farms. Future research is necessary to determine the exact mechanisms responsible for reducing this risk (e.g., removal of residual milk by the calf, lysozymes present in calf saliva, and so on).

Surprisingly, there was an absence of literature addressing other common postpartum diseases and conditions such as metritis, ketosis, and retention of the fetal membrane. In their review, Flower and Weary (2003) address retained fetal membranes and cite the Danish work of Krohn et al. (1990), which highlights a beneficial effect of suckling on lowering the risk of placental retention. Flower and Weary (2003) suggest that this evidence could partially explain the lower incidence of retained fetal membranes in beef compared with dairy cows (Noakes, 1997). Another study demonstrated no effects of immediate calf separation on latency of placental expulsion or placentophagia (Lidfors, 1996). Given the importance of postpartum diseases on the longevity and productivity of dairy cattle (Mulligan and Doherty, 2008), this area of research requires further exploration.

\section{CONCLUSIONS}

The evidence extracted from the included journal articles does not support a recommendation of early dairy cow-calf separation on the basis of calf or cow health. Specifically, the body of literature on calf immunity, mortality, scours, and pneumonia does not indicate that early separation is advantageous. Moreover, there is an absence of literature to suggest that immediate dam-calf separation confers benefits toward mitigating Johne's disease. With respect to cow health, this review indicates that suckling is protective against mastitis.

\section{ACKNOWLEDGMENTS}

We are grateful to Dairy Australia (Melbourne, Australia) for soliciting this review and for providing support to Rebecca Meagher and Annabelle Beaver. We also thank Angela Yu and Auguste de Pennart (both students at the University of British Columbia) for their assistance.

\section{REFERENCES}

Alvarez, F. J., G. Saucedo, A. Arriaga, and T. R. Preston. 1980. Effect on milk production and calf performance of milking crossbred European/Zebu cattle in the absence or presence of the calf, and of rearing their calves artificially. Trop. Anim. Prod. 5:25-37.

Animal Health Australia. 2016. Three step calf rearing plan. Accessed Aug. 10, 2018. https://www.animalhealthaustralia.com.au/what -we-do/endemic-disease/johnes-disease/jd-and-dairy-cattle/three -step-calf-rearing-plan/.
Ansari-Lari, M., M. Haghkhah, A. Bahramy, and A. M. Novin Baheran. 2009. Risk factors for Mycobacterium avium ssp. paratuberculosis in Fars province (Southern Iran) dairy herds. Trop. Anim. Health Prod. 41:553-557.

Atlantic Veterinary College. 2015. Atlantic Johne's Disease Initiative, Risk Assessment Workbook. Accessed Aug. 10, 2018. https://www .atlanticjohnes.ca/files/documents/RAMPNeg.pdf.

Bar-Peled, U., E. Maltz, I. Bruckental, Y. Folman, Y. Kali, H. Gacitua, A. R. Lehrer, C. H. Knight, B. Robinson, H. Voet, and H. Tagari. 1995. Relationship between frequent milking or suckling in early lactation and milk production of high producing dairy cows. J. Dairy Sci. 78:2726-2736.

Beam, A. L., J. E. Lombard, C. A. Kopral, L. P. Garber, A. L. Winter, J. A. Hicks, and J. L. Schlater. 2009. Prevalence of failure of passive transfer of immunity in newborn heifer calves and associated management practices on US dairy operations. J. Dairy Sci. 92:3973-3980.

Beaver, A., P. L. Ruegg, Y. T. Grohn, and Y. H. Schukken. 2016. Comparative risk assessment for new cow-level Mycobacterium avium ssp. paratuberculosis infections between 3 dairy production types: Organic, conventional, and conventional-grazing systems. J. Dairy Sci. 99:9885-9899.

Berghaus, R. D., J. E. Lombard, I. A. Gardner, and T. B. Farver. 2005. Factor analysis of a Johne's disease risk assessment questionnaire with evaluation of factor scores and a subset of original questions as predictors of observed clinical paratuberculosis. Prev. Vet. Med. 72:291-309.

Besser, T., C. C. Gay, and L. Pritchett. 1991. Comparison of three methods of feeding colostrum to dairy calves. J. Am. Vet. Med. Assoc. 198:419-422.

Boonbrahm, N., K. Peters, and C. Kijora. 2004a. The influence of calf rearing methods and milking methods on performance traits of crossbred dairy cattle in Thailand 3. Calf performance. Arch. Tierzucht 47:405-414.

Boonbrahm, N., K. J. Peters, and W. Intisang. 2004b. The influence of calf rearing methods and milking methods on performance traits of crossbred dairy cattle in Thailand -1 . Milk yield and udder health. Arch. Anim. Breed. 47:211-224.

Carias, L., and R. Vaccaro. 1984. Rearing Holstein Friesian and Brown Swiss calves on nurse cows. Trop. Anim. Prod. 9:257-263.

Cetinkaya, B., H. M. Erdogan, and K. L. Morgan. 1997. Relationships between the presence of Johne's disease and farm and management factors in dairy cattle in England. Prev. Vet. Med. 32:253-266.

Cetinkaya, B., H. M. Erdogan, and K. L. Morgan. 1998. Prevalence, incidence and geographical distribution of Johne's disease in cattle in England and the Welsh borders. Vet. Rec. 143:265-269.

Cho, Y. I., and K. J. Yoon. 2014. An overview of calf diarrhea-Infectious etiology, diagnosis, and intervention. J. Vet. Sci. 15:1-17.

Collins, M. T., and I. R. Morgan. 1991. Epidemiological model of paratuberculosis in dairy cattle. Prev. Vet. Med. 11:131-146.

Collins, M. T., D. C. Sockett, W. J. Goodger, T. A. Conrad, C. B. Thomas, and D. J. Carr. 1994. Herd prevalence and geographic distribution of, and risk factors for, bovine paratuberculosis in Wisconsin. JAVMA 204:636-641.

Correia-Gomes, C., D. Mendonça, and J. Niza-Ribeiro. 2010. Risk associations to milk ELISA result for paratuberculosis in dairy cows in northern Portugal using a multilevel regression model. Rev. Med. Vet. (Toulouse) 161:295.

Curtis, C. R., J. M. Scarlett, H. N. Erb, and M. E. White. 1988. Path model of individual-calf risk factors for calfhood morbidity and mortality in New York Holstein herds. Prev. Vet. Med. 6:43-62.

Daugschies, A., and M. Najdrowski. 2005. Eimeriosis in cattle: Current understanding. J. Vet. Med. B 52:417-427.

De Boer, M. W., S. J. LeBlanc, J. Dubuc, S. Meier, W. Heuwieser, S. Arlt, R. O. Gilbert, and S. McDougall. 2014. Invited review: Systematic review of diagnostic tests for reproductive-tract infection and inflammation in dairy cows. J. Dairy Sci. 97:3983-3999.

de Passillé, A. M., P. G. Marnet, H. Lapierre, and J. Rushen. 2008. Effects of twice-daily nursing on milk ejection and milk yield during nursing and milking in dairy cows. J. Dairy Sci. 91:1416-1422. 
Delafosse, A., C. Chartier, M. C. Dupuy, M. Dumoulin, I. Pors, and C. Paraud. 2015. Cryptosporidium parvum infection and associated risk factors in dairy calves in western France. Prev. Vet. Med. 118:406-412.

Dieguez, F. J., I. Arnaiz, M. L. Sanjuan, M. J. Vilar, and E. Yus. 2008. Management practices associated with Mycobacterium avium ssp. paratuberculosis infection and the effects of the infection on dairy herds. Vet. Rec. 162:614-617.

Donat, K., M. Schmidt, H. Köhler, and C. Sauter-Louis. 2016. Management of the calving pen is a crucial factor for paratuberculosis control in large dairy herds. J. Dairy Sci. 99:3744-3752.

Duranti, A., S. M. Caccio, E. Pozio, E. A. Di, C. M. De, A. Battisti, and P. Scaramozzino. 2009. Risk factors associated with Cryptosporidium parvum infection in cattle. Zoonoses Public Health $56: 176-182$.

Edwards, S. A., and D. M. Broom. 1979. The period between birth and first suckling in dairy calves. Res. Vet. Sci. 26:255-256.

Fallon, R. J., and F. J. Harte. 1980. Methods of feeding milk to young calves. Irish J. Agric. Res. 19:67-74.

Faubert, G. M., and Y. Litvinsky. 2000. Natural transmission of Cryptosporidium parvum between dams and calves on a dairy farm. J. Parasitol. 86:495-500.

Flower, F. C., and D. M. Weary. 2003. The effects of early separation on the dairy cow and calf. Anim. Welf. 12:339-348.

Francoz, D., S. Buczinski, A. M. Bélanger, G. Forté, O. Labrecque, D. Tremblay, V. Wellemans, and J. Dubuc. 2015. Respiratory pathogens in Quebec dairy calves and their relationship with clinical status, lung consolidation, and average daily gain. J. Vet. Intern. Med. 29:381-387.

Franklin, S. T., D. M. Amaral-Phillips, J. A. Jackson, and A. A Campbell. 2003. Health and performance of Holstein calves that suckled or were hand-fed colostrum and were fed one of three physical forms of starter. J. Dairy Sci. 86:2145-2153.

Fröberg, S., A. Aspegren-Guldorff, I. Olsson, B. Marin, C. Berg, C. Hernandez, C. S. Galina, L. Lidfors, and K. Svennersten-Sjaunja. 2007. Effect of restricted suckling on milk yield, milk composition and udder health in cows and behaviour and weight gain in calves, in dual-purpose cattle in the tropics. Trop. Anim. Health Prod. 39:71-81.

Fröberg, S., E. Gratte, K. Svennersten-Sjaunja, I. Olsson, C. Berg, A. Orihuela, C. S. Galina, B. Garcia, and L. Lidfors. 2008. Effect of suckling ('restricted suckling') on dairy cows' udder health and milk let-down and their calves' weight gain, feed intake and behaviour. Appl. Anim. Behav. Sci. 113:1-14.

Fulkerson, W. J., R. D. Hooley, and J. K. Findlay. 1978. Improvement in milk production of first calf heifers by multiple suckling. Aust. J. Agric. Res. 29:351-357.

Garro, C. J., G. E. Morici, M. E. Utgés, M. L. Tomazic, and L. Schnittger. 2016. Prevalence and risk factors for shedding of Cryptosporidium spp. oocysts in dairy calves of Buenos Aires province, Argentina. Parasite Epidemiol. Control 1:36-41.

Godden, S. 2008. Colostrum management for dairy calves. Vet. Clin. North Am. Food Anim. Pract. 24:19-39.

González-Sedano, M., B. Marin-Mejia, M. I. Maranto, A. C. Leme de Magalhães-Labarthea, and M. A. Alonso-Diaz. 2010. Effect of residual calf suckling on clinical and sub-clinical infections of mastitis in dual-purpose cows: Epidemiological measurements. Res. Vet. Sci. 89:362-366.

Goodger, W. J., M. T. Collins, K. V. Nordlund, C. Eisele, J. Pelletier, C. B. Thomas, and D. C. Sockett. 1996. Epidemiologic study of on-farm management practices associated with prevalence of $M y$ cobacterium paratuberculosis infections in dairy cattle. J. Am. Vet. Med. A 208:1877-1881.

Gulliksen, S. M., E. Jor, K. I. Lie, T. Løken, J. Åkerstedt, and O. Østerås. 2009a. Respiratory infections in Norwegian dairy calves. J. Dairy Sci. 92:5139-5146.

Gulliksen, S. M., K. I. Lie, T. Loken, and O. Osteras. 2009b. Calf mortality in Norwegian dairy herds. J. Dairy Sci. 92:2782-2795.

Hartman, D. A., R. W. Everett, S. T. Slack, and R. G. Warner. 1974. Calf mortality. J. Dairy Sci. 57:576-578.
Jamali, H., H. W. Barkema, M. Jacques, E. M. Lavallée-Bourget, F. Malouin, V. Saini, H. Stryhn, and S. Dufour. 2018. Invited review: Incidence, risk factors, and effects of clinical mastitis recurrence in dairy cows. J. Dairy Sci. 101:4729-4746.

Jenny, B. F., G. E. Gramling, and T. M. Glaze. 1981. Management factors associated with calf mortality in South Carolina dairy herds. J. Dairy Sci. 64:2284-2289.

Johnsen, J. F., K. A. Zipp, T. Kälber, A. M. de Passille, U. Knierim, K. Barth, and C. M. Mejdell. 2016. Is rearing calves with the dam a feasible option for dairy farms? Current and future research. Appl. Anim. Behav. Sci. 181:1-11.

Johnson-Ifearulundu, Y. J., and J. B. Kaneene. 1998. Managementrelated risk factors for $M$. paratuberculosis infection in Michigan, USA, dairy herds. Prev. Vet. Med. 37:41-54.

Kälber, T., and K. Barth. 2014. Practical implications of suckling systems for dairy calves in organic production systems-A review. Landbauforschung-Ger. 64:45-58.

Kamboj, M., and A. Kumar. 2013. Effect of weaning on performance and behaviour of calves and their dams in dairy cows-A review. Indian J. Anim. Sci. 83:991-997.

Khan, M. A., D. M. Weary, and M. A. G. von Keyserlingk. 2011. Invited review: Effects of milk ration on solid feed intake, weaning, and performance in dairy heifers. J. Dairy Sci. 94:1071-1081.

Klein, D., M. Alispahic, D. Sofka, M. Iwersen, M. Drillich, and F. Hilbert. 2013. Prevalence and risk factors for shedding of thermophilic Campylobacter in calves with and without diarrhea in Austrian dairy herds. J. Dairy Sci. 96:1203-1210.

Kovalcik, K., M. Kovalcikova, and V. Brestensky. 1980. Comparison of the behaviour of newborn calves housed with the dam and in the calf-house. Appl. Anim. Ethol. 6:377-380.

Krohn, C. C., J. Foldager, and L. Mogensen. 1999. Long-term effect of colostrum feeding methods on behaviour in female dairy calves. Acta Agric. Scand. A 49:57-64.

Krohn, C. C., B. Jonasen, and L. Munksgaard. 1990. Cow-calf relations. 2: The effect of 0 vs. 5 days suckling on behaviour, milk production and udder health of cows in different stabling. Report No. 678. National Institute of Animal Science, Foulum, Denmark.

Kvac, M., M. Kouba, and J. Vitovec. 2006. Age-related and housing-dependence of Cryptosporidium infection of calves from dairy and beef herds in South Bohemia, Czech Republic. Vet. Parasitol. 137:202-209.

Lidfors, L. M. 1996. Behavioural effects of separating the dairy calf immediately or 4 days post-partum. Appl. Anim. Behav. Sci. 49:269-283.

Little, D. A., F. M. Anderson, and J. W. Durkin. 1991. Influence of partial suckling of crossbred dairy cows on milk offtake and calf growth in the Ethiopian Highlands. Trop. Anim. Health Prod. 23:108-114.

Lombard, J. E. 2011. Epidemiology and economics of paratuberculosis. Vet. Clin. North Am. Food Anim. Pract. 27:525-535.

Lundborg, G. K., E. C. Svensson, and P. A. Oltenacu. 2005. Herd-level risk factors for infectious diseases in Swedish dairy calves aged 0-90 days. Prev. Vet. Med. 68:123-143.

Maldonado-Camargo, S., E. R. Atwill, J. A. Saltijeral-Oaxaca, and L. C. Herrera-Alonso. 1998. Prevalence of and risk factors for shedding of Cryptosporidium parvum in Holstein Friesian dairy calves in central Mexico. Prev. Vet. Med. 36:95-107.

Marcé, C., P. Ezanno, H. Seegers, D. U. Pfeiffer, and C. Fourichon. 2011. Within-herd contact structure and transmission of Mycobacterium avium subspecies paratuberculosis in a persistently infected dairy cattle herd. Prev. Vet. Med. 100:116-125.

Margerison, J. K., T. R. Preston, and C. J. C. Phillips. 2002. Restricted suckling of tropical dairy cows by their own calf or other cows' calves. J. Anim. Sci. 80:1663-1670.

McAloon, C. G., P. Whyte, L. O'Grady, I. Lorenz, M. G. Green, I. Hogan, A. Johnson, and M. L. Doherty. 2016. Relationship between selected perinatal paratuberculosis management interventions and passive transfer of immunity in dairy calves. Vet. Rec. 179:47.

McGuirk, S. M. 2008. Disease management of dairy calves and heifers. Vet. Clin. North Am. Food Anim. Pract. 24:139-153. 
Mdegela, R., L. Kusiluka, A. M. Kapaga, E. Karimuribo, F. M. Turuka, A. Bundala, F. Kivaria, B. Kabula, A. Manjurano, T. Loken, and D. M. Kambarage. 2004. Prevalence and determinants of mastitis and milk-borne zoonoses in smallholder dairy farming sector in Kibaha and Morogoro districts in Eastern Tanzania. J. Vet. Med. B Infect. Dis. Vet. Public Health 51:123-128.

Meagher, R. K., A. Beaver, D. M. Weary, and M. A. G. von Keyserlingk. 2019. Invited review: A systematic review of the effects of prolonged cow-calf contact on behavior, welfare, and productivity. J. Dairy Sci. 102:5765-5783. https://doi.org/10.3168/jds.2018 $-16021$.

Mejia, C. E., T. R. Preston, and P. Fajersson. 1998. Effects of restricted suckling versus artificial rearing on milk production, calf performance and reproductive efficiency of dual purpose Mpwapwa cattle in a semi-arid climate. Livest. Res. Rural Dev. 10:8.

Mendoza, A., D. Cavestany, G. Roig, J. Ariztia, C. Pereira, A. La Manna, D. A. Contreras, and C. S. Galina. 2010. Effect of restricted suckling on milk yield, composition and flow, udder health, and postpartum anoestrus in grazing holstein cows. Livest. Sci. 127:60-66.

Metz, J., and J. H. M. Metz. 1986. Maternal influence on defecation and urination in the newborn calf. Appl. Anim. Behav. Sci. 16:325-333.

Mohammed, H. O., S. E. Wade, and S. Schaaf. 1999. Risk factors associated with Cryptosporidium parvum infection in dairy cattle in Southeastern New York state. Vet. Parasitol. 83:1-13.

Muktar, Y., G. Mamo, B. Tesfaye, and D. Belina. 2015. A review on major bacterial causes of calf diarrhea and its diagnostic method. J. Vet. Med. Anim. Health 7:173-185.

Mulligan, F. J., and M. L. Doherty. 2008. Production diseases of the transition cow. Vet. J. 176:3-9.

Mulligan, F. J., L. O'grady, D. A. Rice, and M. L. Doherty. 2006. A herd health approach to dairy cow nutrition and production diseases of the transition cow. Anim. Reprod. Sci. 96:331-353.

Muskens, J., A. Elbers, H. J. Van Weering, and J. Noordhuizen. 2003. Herd management practices associated with paratuberculosis seroprevalence in Dutch dairy herds. J. Vet. Med. B Infect. Dis. Vet. Public Health 50:372-377.

Nielsen, S. S., and N. Toft. 2011. Effect of management practices on paratuberculosis prevalence in Danish dairy herds. J. Dairy Sci. 94:1849-1857.

Noakes, D. 1997. Fertility and Obstetrics in Cattle, Edition 2. Blackwell Science, Oxford, UK.

Nocek, J. E., D. G. Braund, and R. G. Warner. 1984. Influence of neonatal colostrum administration, immunoglobulin, and continued feeding of colostrum on calf gain, health, and serum protein. J. Dairy Sci. 67:319-333.

Norton, S., C. Heuer, and R. Jackson. 2009. A questionnaire-based cross-sectional study of clinical Johne's disease on dairy farms in New Zealand. N. Z. Vet. J. 57:34-43.

Pelan-Mattocks, L. S., M. E. Kehrli Jr., T. A. Casey, and J. P. Goff. 2000. Fecal shedding of coliform bacteria during the periparturient period in dairy cows. Am. J. Vet. Res. 61:1636-1638.

Perez, E., J. P. Noordhuizen, L. A. Van Wuijkhuise, and E. N. Stassen. 1990. Management factors related to calf morbidity and mortality rates. Livest. Prod. Sci. 25:79-93.

Pillars, R. B., D. L. Grooms, J. C. Gardiner, and J. B. Kaneene. 2011. Association between risk-assessment scores and individualcow Johne's disease-test status over time on seven Michigan, USA dairy herds. Prev. Vet. Med. 98:10-18.

Quigley, J. D., K. R. Martin, D. A. Bemis, L. N. D. Potgieter, C. R. Reinemeyer, B. W. Rohrbach, H. H. Dowlen, and K. C. Lamar. 1994. Effects of housing and colostrum feeding on the prevalence of selected infectious organisms in feces of Jersey calves. J. Dairy Sci. $77: 3124-3131$

Quigley, J. D., K. R. Martin, D. A. Bemis, L. N. D. Potgieter, C. R. Reinemeyer, B. W. Rohrbach, H. H. Dowlen, and K. C. Lamar. 1995. Effects of housing and colostrum feeding on serum immunoglobulins, growth, and fecal scores of Jersey calves. J. Dairy Sci. 78:893-901.
Rajala, P., and H. Castrén. 1995. Serum immunoglobulin concentrations and health of dairy calves in two management systems from birth to 12 weeks of age. J. Dairy Sci. 78:2737-2744

Ridge, S. E., I. M. Baker, and M. Hannah. 2005. Effect of compliance with recommended calf-rearing practices on control of bovine johne's disease. Aust. Vet. J. 83:85-90.

Rigby, C., J. Ugarte, and R. Boucourt. 1976. Rearing dairy calves by restricted suckling. VII. Effect on mastitis development caused by Staphylococcus aureus. Can. J. Agric. Sci. 10:35-40.

Roth, B. A., K. Barth, L. Gygax, and E. Hillmann. 2009. Influence of artificial vs. mother-bonded rearing on sucking behaviour, health and weight gain in calves. Appl. Anim. Behav. Sci. 119:143-150.

Sanh, M. V., T. R. Preston, and P. Fajersson. 1995. Effects of restricted suckling versus artificial rearing on performance and fertility of Bos taurus and Bos indicus cows and calves in Tanzania. Livest. Res. Rural Dev. 6:29.

Sanh, M. V., T. R. Preston, and L. V. Ly. 1997. Effects of restricted suckling versus artificial rearing on performance and fertility of crossbreed F1 (Holstein Friesian x local) cows and calves in Vietnam. Livest. Res. Rural Dev. 6:29.

Sargeant, J. M., and A. M. O'Connor. 2014. Issues of reporting in observational studies in veterinary medicine. Prev. Vet. Med. 113:323-330.

Seegers, H., C. Fourichon, and F. Beaudeau. 2003. Production effects related to mastitis and mastitis economics in dairy cattle herds. Vet. Res. 34:475-491.

Selman. I. E., A. D. McEwan, and E. W. Fisher. 1971. Absorption of immune lactoglobulin by newborn dairy calves. Attempts to produce consistent immune lactoglobulin absorptions in newborn dairy calves using standardised methods of colostrum feeding and management. Res. Vet. Sci. 12:205-210.

Stěhulová, I., L. Lidfors, and M. Špinka. 2008. Response of dairy cows and calves to early separation: Effect of calf age and visual and auditory contact after separation. Appl. Anim. Behav. Sci. 110:144-165.

Stewart, S., S. Godden, R. Bey, P. Rapnicki, J. Fetrow, R. Farnsworth, M. Scanlon, Y. Arnold, L. Clow, K. Mueller, and C. Ferrouillet. 2005. Preventing bacterial contamination and proliferation during the harvest, storage, and feeding of fresh bovine colostrum. J. Dairy Sci. 88:2571-2578.

Stott, G. H., D. B. Marx, B. E. Menefee, and G. T. Nightengale. 1979. Colostral immunoglobulin transfer in calves. IV. Effect of suckling. J. Dairy Sci. 62:1908-1913.

Svensson, C., K. Lundborg, U. Emanuelson, and S. Olsson. 2003. Morbidity in Swedish dairy calves from birth to 90 days of age and individual calf-level risk factors for infectious diseases. Prev. Vet. Med. 58:179-197.

Tavornpanich, S., W. O. Johnson, R. J. Anderson, and I. A. Gardner. 2008. Herd characteristics and management practices associated with seroprevalence of Mycobacterium avium ssp. paratuberculosis infection in dairy herds. Am. J. Vet. Res. 69:904-911.

Thomas, G. W., S. A. Spiker, and F. Mickan. 1981. Influence of suckling by Friesian cows on milk production and anoestrus. Aust. J. Exp. Agric. 21:5-11.

Tiwari, A., J. A. VanLeeuwen, I. R. Dohoo, G. P. Keefe, J. P. Haddad, H. M. Scott, and T. Whiting. 2009. Risk factors associated with Mycobacterium avium ssp. paratuberculosis seropositivity in Canadian dairy cows and herds. Prev. Vet. Med. 88:32-41.

Trotz-Williams, L. A., K. E. Leslie, and A. S. Peregrine. 2008b. Passive immunity in Ontario dairy calves and investigation of its association with calf management practices. J. Dairy Sci. 91:3840-3849.

Trotz-Williams, L. A., S. W. Martin, K. E. Leslie, T. Duffield, D. V. Nydam, and A. S. Peregrine. 2008a. Association between management practices and within-herd prevalence of Cryptosporidium parvum shedding on dairy farms in southern Ontario. Prev. Vet. Med. 83:11-23.

Trotz-Williams, L. A., S. Wayne Martin, K. E. Leslie, T. Duffield, D. V. Nydam, and A. S. Peregrine. 2007. Calf-level risk factors for neonatal diarrhea and shedding of Cryptosporidium parvum in Ontario dairy calves. Prev. Vet. Med. 82:12-28. 
USDA. 2007. National Health Monitoring System. Dairy 2007 Part IV: Reference of Dairy Cattle Health and Management Practices in the United States, 2007. https://www.aphis.usda.gov/animal health/nahms/dairy/downloads/dairy07/Dairy07_allpubs.pdf.

USDA. 2010. Uniform Program Standards for the Voluntary Bovine Johne's Disease Control Program. https://johnes.org/handouts/ files/USDA_Program_Standards_Sept-2010.pdf.

USDA. 2016. Dairy 2014, Dairy Cattle Management Practices in the United States, 2014. USDA-APHIS-VS-CEAH-NAHMS. Accessed Dec. 12, 2018. https://www.aphis.usda.gov/animal_health/ nahms/dairy/downloads/dairy14/Dairy14_dr_PartI.pdf.

USDA. 2018. National Health Monitoring System. Dairy 2014: Health and Management Practices on U.S. Dairy Operations, 2014. Accessed Aug. 10, 2018. https://www.aphis.usda.gov/animal_health/ nahms/dairy/downloads/dairy14/Dairy14_dr_PartIII.pdf.

Ventorp, M., and P. Michanek. 1992. The importance of udder and teat conformation for teat seeking by the newborn calf. J. Dairy Sci. 75:262-268.

Wagenaar, J. P. T. M.,, P. Klocke, G. Butler, G. Smolders, J. H. Nielsen, A. Canever, and C. Leifert. 2011. Effect of production system, alternative treatments and calf rearing system on udder health in organic dairy cows. NJAS Wagen. J. Life Sci. 58:157-162.

Wagenaar, J. P. T. M., and J. Langhout. 2007. Practical implications of increasing 'Natural living' through suckling systems in organic dairy calf rearing. NJAS Wagen. J. Life Sci. 54:375-386.
Walsh, J. P. 1974. Milk secretion in machine-milked and suckled cows Isr. J. Agric. Res. 13:77-89.

Waltner-Toews, D., S. W. Martin, and A. H. Meek. 1986. Dairy calf management, morbidity and mortality in Ontario Holstein herds. III. Association of management with morbidity. Prev. Vet. Med. 4:137-158.

Weary, D. M., and B. Chua. 2000. Effects of early separation on the dairy cow and calf: 1 . Separation at $6 \mathrm{~h}, 1$ day and 4 days after birth. Appl. Anim. Behav. Sci. 69:177-188.

Wells, S. J., and B. Wagner. 2000. Herd-level risk factors for infection with Mycobacterium paratuberculosis in US dairies and association between familiarity of the herd manager with the disease or prior diagnosis of the disease in that herd and use of preventive measures. J. Am. Vet. Med. Assoc. 216:1450.

Wells, S. J., D. A. Dargatz, and S. L. Ott. 1996. Factors associated with mortality to 21 days of life in dairy heifers in the United States. Prev. Vet. Med. 29:9-19.

Whiting, P., J. Savović, J. P. Higgins, D. M. Caldwell, B. C. Reeves, B. Shea, P. Davies, J. Kleijnen, and R. Churchill. 2016. ROBIS: A new tool to assess risk of bias in systematic reviews was developed. J. Clin. Epidemiol. 69:225-234.

\section{APPENDIX}

\section{Bias Assessment of Systematic Review Methodology}

Using material sourced from domains 1 and 2 of ROBIS (Risk of Bias in Systematic Reviews, Whiting et al., 2016), we have attempted to identify and address weaknesses in our methodology.

We restricted our initial literature screening to a single search engine (WoS), as different search engines employ distinct criteria and weightings to generate search results. In addition, the search terms themselves require alteration across different databases; certain search engines automatically account for similar terms whereas others do not. It therefore becomes difficult to integrate reference lists that have been generated based upon unique algorithms. We considered WoS to be the best available resource for our search due to its status as a human-curated database with itemized, structured entries. Additionally, WoS only provides results from journals indexed by Clarivate Analytics and filters out non-peer-reviewed literature; however, articles from well-known, high-impact-factor journals may be overrepresented in our results.

The use of a single search engine may be considered a weakness of the present review. Thus, we have attempted to validate this approach by conducting targeted searches in PubMed to ensure no additional articles were discoverable. First, we ran the exact searches as listed in Materials and Methods in PubMed. Results indicated that no exact match was found for the phrases "reared by the dam," "reared by cows," "reared by the mother," and "calf contact with adults." Therefore, these phrases were removed to ensure that PubMed would not search within the quoted phrases. Our final PubMed search included the following fixed set: ("cowcalf" OR "cow/calf" OR "dam-calf" OR "dam/calf" OR "dam rearing" OR "suckling system" OR "mother rearing") AND (nurs* OR suckl* OR separation OR contact OR "risk factor*") AND (calf OR calves). In addition, the following targeted terms were included: (scour* OR diarr*) OR (cryptosporidi*) OR ("Johne's" OR paratuberculosis) OR (pneumonia OR respiratory) OR (immunity OR "passive transfer") OR (disease OR diseases OR diseased OR infection OR health OR morbidity OR mortality) OR (mastitis OR "intramammary infection*" OR "udder health"). A total of 61 articles were uncovered in these searches; 42 of these were duplicates from our WoS searches. Of the 19 unique articles, 10 pertained to beef cattle or other species and were therefore excluded. The titles and abstracts of the 9 remaining articles were scanned, and 7 were considered to be irrelevant to the main research question. Two full texts were reviewed and neither study made a direct comparison between cow or calf health in suckling or cow-calf contact systems and conventional rearing. PubMed searches were then conducted for all terms that yielded no results in WoS (as listed in Materials and Methods). No additional relevant results were identified.

The "Topic" field of WoS generates searches of the article title, abstract, and keywords, but not the body of the manuscript. Papers assessing a variety of risk factors for a given disease may therefore have been overlooked, particularly if the risk factor of interest was not significantly associated with cow-calf contact. 
Thus, it is conceivable that the results of the WoS queries reported here demonstrate a bias away from the null. Fortunately, this bias is expected to be present in both directions and is therefore unlikely to affect overall conclusions.

To counter this undesired selectivity, we searched within reference lists to uncover additional papers. It must be acknowledged that the authors of these papers may be more inclined to cite papers in agreement with their own conclusions, but this type of selection bias is likely to arise in any systematic review using reference lists as additional resources. Similarly, although we placed no restriction on publication year, we did not locate any manuscripts published in 2017 or 2018, since very recent papers tend to have fewer citations (from even more recent manuscripts).

In the initial scans of the reference lists, we only selected papers with titles that alluded to a potential comparison of cow or calf health in different rearing conditions. For example, a hypothetical paper titled "Management decisions linked to heightened prevalence of Cryptosporidium oocysts" would have been considered, whereas a paper titled "Cryptosporidium parvum in cattle" would not have been investigated further. We may have missed papers that, in spite of a more general title, had in fact addressed the topic in question. This assessment is unavoidably qualitative. It is not possible to measure the number of primary literature articles that may have been overlooked due to our methodology; this highlights the importance of accurate and descriptive key words in manuscripts as emphasized by De Boer et al. (2014).

We excluded conference proceedings (both papers and abstracts), as well as book chapters, as we could not be certain that these sources had been peer reviewed. We also excluded literature in languages other than English, as we were unable to critically assess the methods and evaluate the results. We are unable to determine to what extent these exclusions affected the conclusions of this review.

\section{Quality Assessment of Included Articles}

To provide an inclusive overview of the topic in question, no exclusion criteria were developed concerning sample size, study quality, or journal quality. Here we provide a quality assessment of the included journal articles on the basis of study design, thoroughness of reporting, and potential biases.

In the field of human medicine, randomized controlled trials are typically considered the gold standard, and observational research is sometimes excluded from systematic reviews. The number of randomized controlled trials in agriculture and veterinary medicine is comparatively low (Sargeant and O'Connor, 2014), so observational studies are often included out of necessity. With reference to study design, 28 articles in our systematic review $(40 \%)$ were experimental or quasi-experimental and $42(60 \%)$ were observational. Randomization procedures for animals were described or referenced in 13 studies ( $46 \%$ of the experimental studies), but only 2 included some type of blinding (blinding was likely not feasible for some measures, given the obvious differences in management between groups with different levels of maternal contact). Random assignment of animals to treatment groups was described in 14 of the single-herd trials (48\%), and random selection of herds (or a random selection of animals within herds) was described in $24(59 \%)$ of the multi-herd studies.

In Tables 1 to 6 , we have reported the authors' conclusions concerning their data, regardless of whether these conclusions were tested using inferential statistics. Of the 70 included papers, 16 (23\%) either did not confirm their conclusions using statistical testing or failed to report results. In these instances, the reported results often reflected secondary research objectives or descriptive information. As per the inclusion criteria, papers investigating other aspects of cow and calf contact or separation as a primary objective were not excluded, as long as health-related measures were also reported. A further 3 studies (4\%) reported conclusions based upon a $0.1 \alpha$-level threshold. These papers are indicated with footnotes in their respective tables.

Study limitations, potential biases, and sources of error were formally discussed in 16 manuscripts (23\%), although only 1 paper included an assessment of inter-observer reliability. Some level of missing data was reported in 15 studies (21\%), with explanation for the missing data provided in 7 of these. Seven of the single-herd studies $(24 \%)$ did not contain complete information on the type and duration of cow-calf contact and feeding regimens for control groups. Interestingly, $7(10 \%)$ of papers failed to provide information on country or region in which the study was conducted (although the authors' affiliations and the location of laboratories used for sample analysis most often suggested that these studies were conducted in the United States). An additional 16 studies (23\%) did not include any information pertaining to cattle breed (of these, 15 were multi-herd trials).

For manuscripts addressing Johne's disease, cryptosporidiosis, or mastitis, 37 (90\%) adequately discussed the diagnostic test used, although only $13(32 \%)$ cited the sensitivity or specificity (or both) of the implemented diagnostic. Of the 5 articles in the immunity section that made reference to FPT, only $2(40 \%)$ provided 
a full definition for the condition and $2(40 \%)$ offered rationales or citations supporting the diagnostic cut points implemented.

\section{Inconsistencies in Methods and Common Problems}

In the single-herd studies, there was a high variability in what constituted control groups in terms of the level of maternal contact. For example, in 10 of these studies, control calves were given less than $24 \mathrm{~h}$ of contact with the dam; in a further 9 studies, control animals were provided with a minimum of $3 \mathrm{~d}$ of unrestricted dam-calf contact. The feeding regimens were also different across studies. These discrepancies are likely to have affected conclusions, and thus it is difficult to make direct comparisons between articles. Even in studies seemingly describing the same treatment (e.g., "restricted suckling"), the implementation of these treatments was variable. For example, in Mejia et al. (1998) calves in the "restricted suckling" group were permitted suckling for 30 min after milking (with one quarter left unmilked), twice daily for 6 mo. In contrast, in Fulkerson et al. (1978), calves were reunited with the dam once per day (for an unspecified amount of time) for approximately 1 mo. Further, in several studies (e.g., Fallon and Harte, 1980; Nocek et al., 1984), dam-calf suckling is referenced, but the duration of contact between cows and calves in the control group is not described.
Several of the older studies had low sample sizes and are more accurately interpreted as case reports. At one extreme, Rigby et al. (1976) presented conclusions regarding mastitis based upon a single cow nursing her calf; however, most of the other studies with small sample sizes were able to enroll at least 30 animals.

Due to the variability in study type, methodology, use of controls, and the amount of information provided, it was not feasible to conduct a meta-analysis. We provided risk ratios, prevalence ratios, and odds ratios where possible, but the variation in study methodology prevented us from generating a meaningful estimate of the overall magnitude of the effects considered. Instead, only the direction of association was highlighted, and our discussion is mainly based upon on the number of positive and negative associations. A weakness of this approach is that it weighs equally all studies, regardless of sample size, effect size, and any weaknesses in design and interpretation.

It is important to consider that no temporal relationship between management factors (e.g., cow-calf separation) and outcomes (e.g., disease) has been examined in the included cross-sectional studies. Thus, management decisions could plausibly have been implemented in response to the disease in question, rather than representing a risk factor for disease. 